\title{
Symptom burden among people with chronic disease
}

\author{
Jeanette Eckerblad
}

\author{
Division of Health, Activity and Care \\ Department of Social and Welfare Studies \\ Linköping University, Sweden \\ Linköping 2015
}

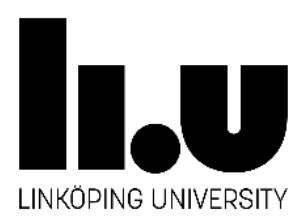


Title

Symptom burden among people with chronic disease

(CJeanette Eckerblad, 2015

Cover picture by: Eva Eckerblad

Published article has been reprinted with the permission of the copyright holder.

Printed in Sweden by LiU-Tryck, Linköping, Sweden, 2015

ISBN: 978-91-7685-939-1

ISSN 0345-0082 
To my family

Bo, Rebecca and Robin.

"It always seems impossible until it's done." — Nelson Mandela 



\section{CONTENTS}

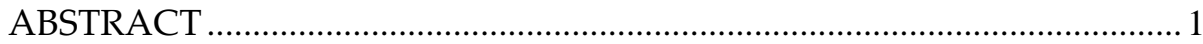

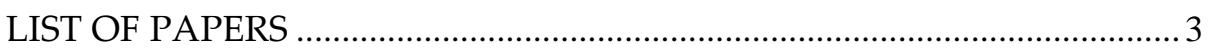

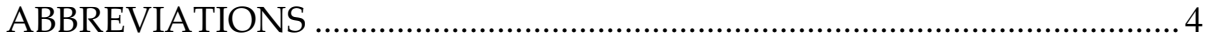

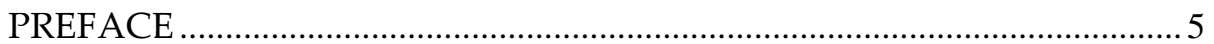

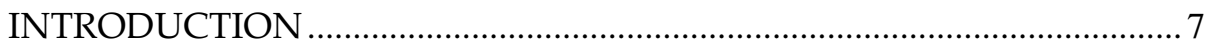

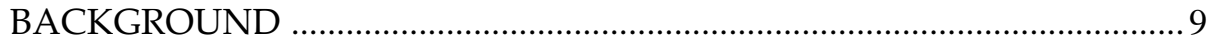

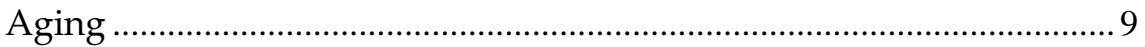

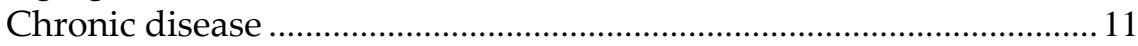

Symptom theories and concepts..................................................... 14

Organizing care for people with multimorbidity ............................... 18

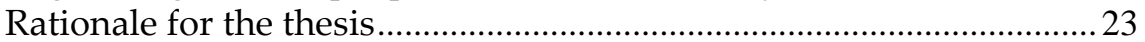

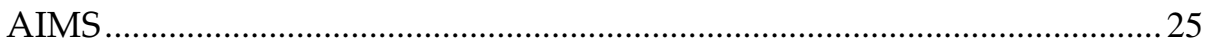

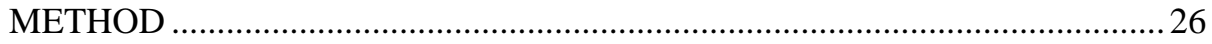

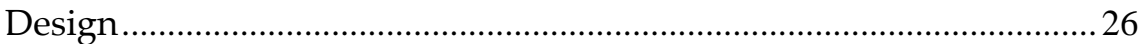

Participants and Procedures ......................................................... 27

Intervention used in the AGe-FIT study ......................................... 33

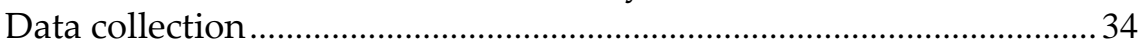

Background variables and participants characteristics........................35

The Memorial Symptom Assessment Scale. ...................................... 36

The Mini Mental State Exam ................................................................. 39

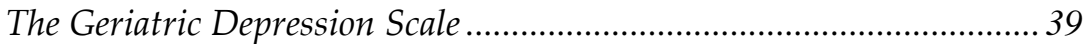

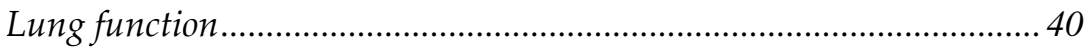

Self-perceived physical and emotional health ..................................... 40

Qualitative interviews........................................................................ 41

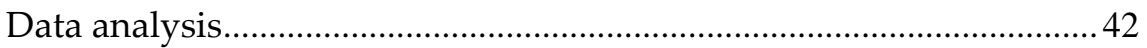

Ethical approval and considerations ............................................. 45

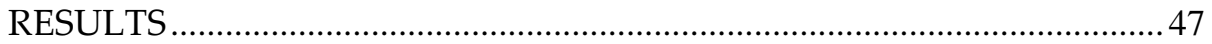

Background variables and characteristics......................................... 47

Symptom burden ........................................................................... 49

Factors related to symptom burden .................................................. 51

Symptom burden assessed with the MSAS ...................................... 51 


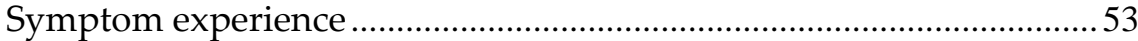

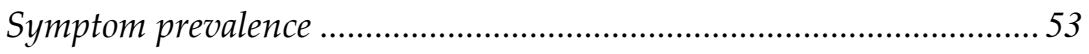

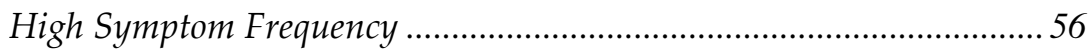

High Symptom Severity .................................................................. 57

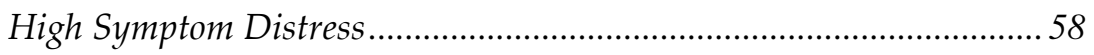

MSAS subscale scores ....................................................................... 60

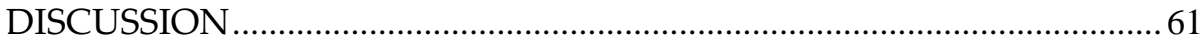

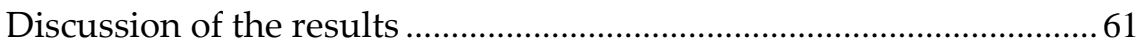

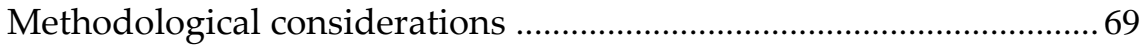

Validity Reliability and Trustworthiness .............................................. 69

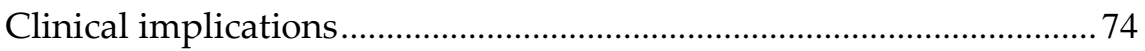

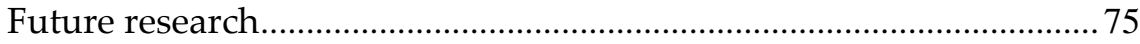

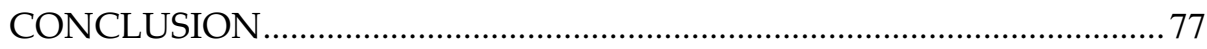

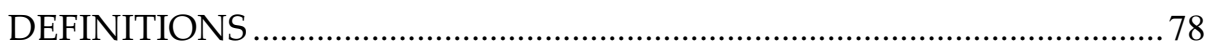

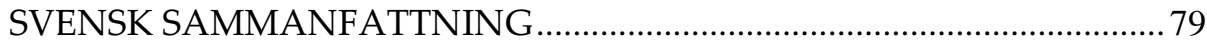

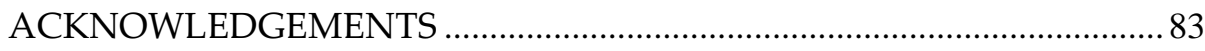

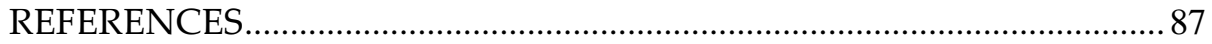




\section{ABSTRACT}

Introduction: Chronic diseases tend to increase with old age. Older people with chronic disease are commonly suffering from conditions which produce a multiplicity of symptoms and a decreased health-related quality of life. Nurses have a responsibility to prevent, ease or delay a negative outcome through symptom management, or assist in achieving an acceptable level of symptom relief.

Aim: The overall aim of the thesis was to describe different aspects of symptom burden from the perspective of community-dwelling people with chronic disease.

Methods: This thesis is based upon four papers that used both quantitative and qualitative data to describe different aspects of symptom burden experienced by people with chronic diseases. Paper I is a cross-sectional study with 91 participants diagnosed with chronic obstructive pulmonary disease. Papers II and IV are based upon secondary outcome data from a randomized controlled trial with 382 community-dwelling older people with multimorbidity. Paper II is a cross-sectional study and paper IV has a descriptive and an explorative design reporting on the trajectory of symptom prevalence and symptom burden. Paper III is a qualitative study with participants from the AGe-FIT 
Results: Among people diagnosed with COPD the most prevalent symptoms with the highest symptom burden scores were shortness of breath, dry mouth, cough, sleep problems, and lack of energy, with just a few differences between participants with moderate and severe airflow limitation (I). For older people with multimorbidity, pain was the symptom with the highest prevalence and burden. Other highly prevalent symptoms were lack of energy and a dry mouth. Poor vision, likelihood of depression, and diagnoses of the digestive system were independently related to the total symptom burden score (II). The symptoms experienced by the older people were persistent and the symptom burden remained high over time (IV). The experience of living with a high symptom burden was described as an endless struggle. The analysis revealed an overall theme, "To adjust and endure" and three sub-themes, "to feel inadequate and limited", "to feel dependent", and "to feel dejected" (III).

Conclusions: The results of this thesis indicate the importance of early symptom identification. People with chronic diseases have an unmet need for optimized treatment that focuses on the total symptom burden, and not only disease specific symptoms. A large proportion of older people with multimorbidity suffer a high and persistent symptom burden, and the prevalence and trajectory of pain are high. Older people sometimes think their high age is the reason they experience a diversity of symptoms, and they do not always communicate these to their health-care provider. Keywords: Symptom experience, Symptom burden, Chronic disease, Community-dwelling. 


\section{LIST OF PAPERS}

This thesis is based upon the four following papers and they will be referred to in the text by their Roman numerals.

(I) Jeanette Eckerblad, Kristina Tödt, Per Jakobsson, Mitra Unosson, Elisabeth Skargren, Magnus Kentsson, Kersti Theander. Symptom burden in stable COPD patients with moderate or severe airflow limitation. Heart and Lung 2014; 43:351-7. DOI. 10.1016/j.hrtlng.2014.04.004

(II) Jeanette Eckerblad, Kersti Theander, Anne Ekdahl, Mitra Unosson, Ann-Britt Wirehn, Anna Milberg, Barbro Krevers, Tiny Jaarsma. Symptom burden in community-dwelling older people with multimorbidity: a cross-sectional study. BMC Geriatrics 2015; 15:1. DOI.10.1186/1471-2318-15-1

(III) Jeanette Eckerblad, Kersti Theander, Anne Ekdahl, Tiny Jaarsma, Ingrid Hellström. To adjust and endure: a qualitative study of symptom burden in older people with multimorbidity. Applied Nursing Research 2015; 28:322-7.

DOI.10.1016/j.apnr.2015.03.008

(IV) Jeanette Eckerblad, Kersti Theander, Anne Ekdahl, Tiny Jaarsma. Symptom trajectory and symptom burden in older people with multimorbidity, data from the RCT AGe-FIT study. (Submitted) 


\section{ABBREVIATIONS}

COPD

CGA

AGU

AGe-FIT

RCT

ICD

TOUS

SMT

IG

CG

GDS

MMSE

BMI

FEV

MSAS

TMSAS

MSAS-GDI

MSAS-PHYS

MSAS-PSYCH
Chronic Obstructive Pulmonary Disease

Comprehensive geriatric assessment

Ambulatory Geriatric Unit

The Ambulatory Geriatric Assessment

- a Frailty Intervention

Randomized Controlled Trial

International Classification of Diseases

Theory Of Unpleasant Symptoms

Symptom Management Theory

Intervention Group

Control Group

Geriatric Depression Scale

Mini-Mental State Exam

Body Mass Index

Forced Expiratory Volume

Memorial Symptom Assessment Scale

Total MSAS score

Global Distress Index

Physical Symptom Subscale score

Psychological Symptom Subscale score 


\section{PREFACE}

While I have been working as a nurse and teacher for the past 20 years, I have noticed that symptoms are central in most contexts and encounters. Symptoms are often what drives people to seek help from their health-care provider. At the same time, symptoms are a central part of health-care and drive nursing students' learning both in theoretical and in clinical practice.

When I was asked to participate in a research project with a focus on fatigue and other aspects of chronic obstructive pulmonary disease (COPD) I did not hesitate. I had met people suffering from this disease during clinical work both in the medical ward and in the intensive care unit. The symptom instrument that was used in the study measured 32 different symptoms in terms of their prevalence, frequency severity and distress. During the analysis of the data on symptoms I realized the importance of disease-specific and general symptoms, but also the importance of getting all the dimensions assessed that symbolized the symptom burden.

During the analysis of the data on people diagnosed with COPD, I started to wonder about the disease specific approach. Often people with COPD have more than one medical diagnose. At that time I was invited to participate in a research project that was not focused on a single disease but on people with multimorbidity. This was a randomized controlled trial (RCT), with data assessment at baseline, one and two years. This would 
give me the opportunity to follow the symptom trajectory and see changes over time, something that was lacking or sparsely described in earlier symptom research.

The participants in the RCT had a variety of severe and distressing symptoms. As the data collection went on the participants often wanted to tell me more about their symptom, what life was like living with all of these symptoms and how they managed everyday life. This was another aspect of the symptom experience and one that I could not get from the symptom instrument. Many stories have been entrusted to me and they have helped me get a fuller understanding of the meaning of the term 'A high symptom burden'.

// Jeanette Eckerblad 


\section{INTRODUCTION}

Globally, the population is aging and people can live with several chronic diseases for decades. The number of people living with chronic diseases is increasing throughout the world and one public health goal for the aging society is to reduce the impact of chronic diseases. Chronic diseases among older people are considered to be one of the largest health-care challenges of this century, something that will affect both the socioeconomic and the health-care systems (WHO 2014). To manage this challenge, more knowledge is needed. To understand older people's perceptions of health and illness in order to facilitate better delivery of appropriate health-care to this group is a start (Elias and Lowton 2014). A chronic disease often inflicts different symptoms, but the way a person perceives and responds to illness is a unique experience. Lack of adequate symptom control may result in a significant deterioration the health-related quality of life (Newcomb 2010, Santos-Eggimann et al. 2009). People who live with a high burden of symptoms have an increased need of health-care utilization such as visits to the emergency department and a higher risk of hospitalization (Salanitro et al. 2012) or admission to a nursing home (Sheppard et al. 2013). A high symptom burden is also associated with higher health-care costs (Wolff et al. 2002, Condelius et al. 2007). Research concerning symptoms has so far mostly been focussed on people in the most advanced stages of a single disease (Blinderman et al. 2008, Blinderman et al. 2009) such as COPD, heart failure or cancer, or is focused on a single symptom (Theander and Unosson 2011, Theander and Unosson 2004, Fierro-Carrion 
et al. 2004). In order to prevent chronic diseases to deteriorate, symptom maintenance and early symptom detection is necessary (Vestbo et al. 2013, McMurray et al. 2012). To lower the impact of chronic diseases it is essential that a holistic approach towards people with chronic disease is applied, together with an assessment of the total symptom burden. 


\section{BACKGROUND}

\section{Aging}

The population throughout Europe is getting older (EU 2014), and in Sweden the average life expectancy is nearly 84 years for women and 80 years for men. The mean age is expected to increase by approximately 5 years for women and 7 years for men, during the next 40 years (SCB 2015) (Figure 1). Sweden has one of the highest proportions of people above 80 years in the world and there is a high proportion of people with a growing, existing or up-coming need of health- and social care due to disease and illness (Larsson and Thorslund 2006).

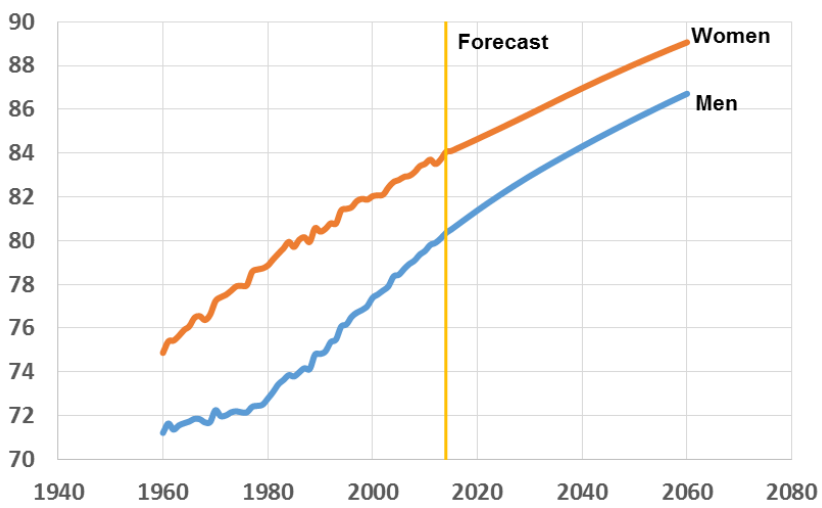

Figure 1. Life expectancy in Sweden by sex 1960-2014 and forecast 2015-2060. Source SCB, statistics Sweden 2015 (reprinted with permission from $\mathrm{SCB}$ ) 
In general, age is often referred to as years since birth (chronologically) which is a clear and efficient way of measuring age. When people attain a certain age in years, they are allowed or mature to do various things, for example, get a driver's license (SFS 1998), vote in an election (SFS 1997) or retire from work with an old -age pension (SFS 2010).

However there is a growing acceptance that not everyone age the same way or at the same rate. Human aging is a process that occurs both in the biological, psychological and social domains (Dziechciaż and Filip 2014). Biological theories of aging focus on the belief that aging is part of the organism's design, but acknowledge that social and environmental factors also are important factors (Kane 2013). Most of our bodily organ systems seem to lose function by approximately $1 \%$ per year, beginning when people are in their 20-30s, leading to a gradual deterioration (Kane 2013). Biological aging is associated with a gradual loss of homeostatic mechanisms (Kane 2013). Psychological aging is often referred to as secondary to the biological aging. Psychological aging reflects the adaptability and awareness of the aging process and the ability to adjust to new situations and the adverse effects of deterioration in the cognitive and intellectual functions (Dziechciaż and Filip 2014). Social aging is linked to the ability to adapt to the change, or loss of social roles. The way a person perceives the aging process and relates to it is often connected to the society in which they live. The culture of the Western world promotes youth, efficiency and cost-effectiveness, which makes it more difficult for older people to be personally fulfilled (Dziechciaż and Filip 2014). 
The difference between normal aging and pathological changes can sometimes be difficult to recognize and it is often difficult to draw a sharp line between normal aging and disease in older people (Larsson and Thorslund 2006). Symptoms and illness, however, should not be considered a normal part of aging (Stewart et al. 2012). As our life expectancy increases it has become clear that besides measuring age by years from birth, there is a need for other ways of looking at aging. Age has previously been divided into three phases: childhood, adulthood and old age (Christensen et al. 2009). With a growing population of people living longer, the third "old age" has been divided in two parts, third age (young old) and fourth age (oldest old). While the third age is often symbolized by an enjoyable life full of opportunities, the fourth age is symbolized by growing health problems, disabilities and frailty (Gilleard and Higgs 2013, Larsson and Thorslund 2006). It is impossible to estimate the time each individual will remain in each phase (Gilleard and Higgs 2013). This thesis mainly focuses mostly on people in the fourth age.

\section{Chronic disease}

Chronic diseases are also known as non-communicable diseases and are the leading cause of mortality in the world. Chronic diseases have in general a long duration but a slow progress (WHO 2014). In Sweden, chronic diseases such as heart disease, stroke, cancer, chronic respiratory diseases and diabetes are responsible for $90 \%$ of all deaths (figure 2) (WHO 2014). The majority of all people above 75 years are diagnosed with more than one chronic disease (Fratiglioni L 2010). One of the common chronic diseases worldwide is COPD, it is predicted to become the third-leading 
cause of death by 2020 (Vestbo et al. 2013) The majority, or almost all people diagnosed with COPD (96\%) of those above 45 years of age have at least one other chronic disease (Negewo et al. 2015). COPD is associated with co-morbidities such as ischemic heart disease, diabetes, skeletal muscle wasting, cachexia, osteoporosis, depression, and lung cancer (Decramer et al. 2012).

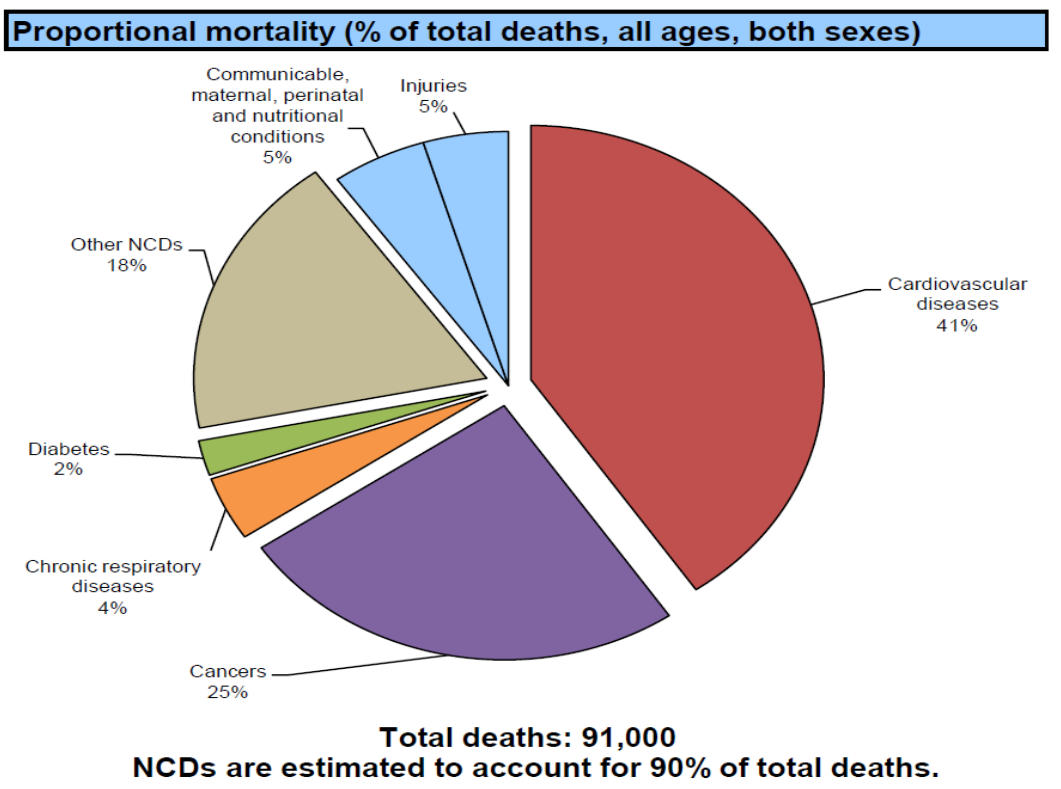

Figure 2 Country profile, non-communicable diseases in Sweden, 2014 from the World Health Organization Total population: 9511000 , Income Group: High (reprint with permissions@who.int.)

People diagnosed with COPD experience a slow decline in lung function and health over time (Vestbo et al. 2013). In its early stages, COPD is usually not recognized, diagnosed, or treated, as many patients seek health-care attention only after substantial damage has occurred to the 
lungs, and related symptoms are present (Lindberg et al. 2006, Vestbo et al. 2013). Although symptoms serve as a focus for diagnoses and treatment of COPD, most symptom knowledge is based on studies of patients with severe or very severe airflow limitations (Tranmer et al. 2003, Walke et al. 2004, Blinderman et al. 2009). There is limited knowledge of the symptom experience in patients with moderate airflow limitation.

Apart from COPD there are several other chronic diseases that are increasingly prevalent in older people. Even though chronic diseases are not limited to older age, the number of chronic diseases increases as people grow older. Approximately $50-80 \%$ of people above 65 years and more than $70 \%$ of people aged above 80 years have been reported to suffer from multimorbidity (Boeckxstaens and De Graaf 2011), assuming that multimorbidity is defined as the occurrence of two or more chronic diseases at the same time. This is a definition that is frequently used and has been sanctioned by WHO (Condelius et al. 2007, WHO 2008).

There are however other ways of describing and defining multimorbidity. While the epidemiological perspective focuses on mapping the prevalence of multimorbidity, the clinical perspective tries to identify people at risk of negative outcomes. In an attempt to identify "frail older people" with multimorbidity with extensive need of care, the Swedish National Board of Health and Welfare and Swedish National Centre of Epidemiology proposed the following definition: "Individuals 75 years old or older, who during the past 12 months have received inpatient hospital care three or 
more times and who have three or more diagnoses in three or more diagnostic groups according to the classification system ICD-10"(Gurner and Thorslund $2001^{\mathrm{p} .2597}$ ). This definition is used for defining and including people with multimorbidity in this thesis and it corresponds well with the "fourth age", the last stage in life when people can no longer manage without help from others (Fratiglioni L 2010).

Regardless of what definition is used to define multimorbidity, it is a common condition and previous studies have shown that it is associated with older age, female gender and living under lower socioeconomic conditions (Schäfer et al. 2012). People with multimorbidity have a higher mortality risk than other people but the severity of the disease is more important than the actual number of concurrent diseases (Fratiglioni L 2010). Multimorbidity often results in a poor health related quality of life, disability and functional decline (Marengoni et al. 2011), and people diagnosed with chronic diseases do often suffer from a variety of concurrent symptoms (Walke et al. 2004, Zambroski et al. 2005, Tranmer et al. 2003)

\section{Symptom theories and concepts}

Symptom management is central to nursing practice and an important focus for nursing science (Smith 2014b). Both signs and symptoms are related to significant clinical problems for patients suffering from chronic diseases. If symptoms are successfully assessed and managed quality of life might be improved (Jablonski et al. 2007). A symptom is defined as a "subjective experience reflecting the bio-psycho-social functioning, 
sensations or cognition of an individual". A signs is defined as "an abnormality indicative of disease that is detectable by the individual or by

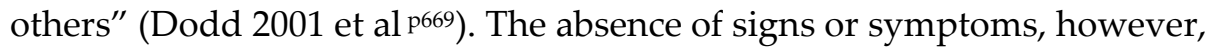
does not necessarily mean that a person has optimal health (Dodd et al 2001). According to the Theory Of Unpleasant Symptoms (TOUS) a symptom may differ from one illness to another, but the experience of several symptom dimensions is common. These dimensions include: intensity (strength or severity), timing (duration and frequency of occurrence), level of perceived distress (degree of discomfort or inconvenience), and quality (what a symptom feels like). These dimensions are assumed to be both separate and related to one another and are all included in a multidimensional symptom profile (Lenz et al. 1997)

The Memorial Symptom Assessments Scale (MSAS) (Portenoy et al. 1994) is a self-rated instrument developed to provide a multidimensional symptom profile. The instrument provides information on symptom prevalence, frequency, severity and distress. However, it does not include the quality dimension previously described by the TOUS (Smith 2014b). A multidimensional symptom profile gives health-care providers more information in each symptom. The symptoms reported to be most severe are not always the ones causing the highest distress. Even symptoms with a mild intensity can be perceived as highly distressing and very bothersome (Walke et al. 2006). Although the TOUS gives a good description of the different symptom dimension, and is applicable for multiple symptoms, the Symptom Management Theory (SMT) (Smith 2014a) and the revised conceptual model of symptom management (Figure 
3) (Dodd et al 2001) are used in this thesis to understand the symptom experience in people with chronic disease.

\section{Symptom Management Model}

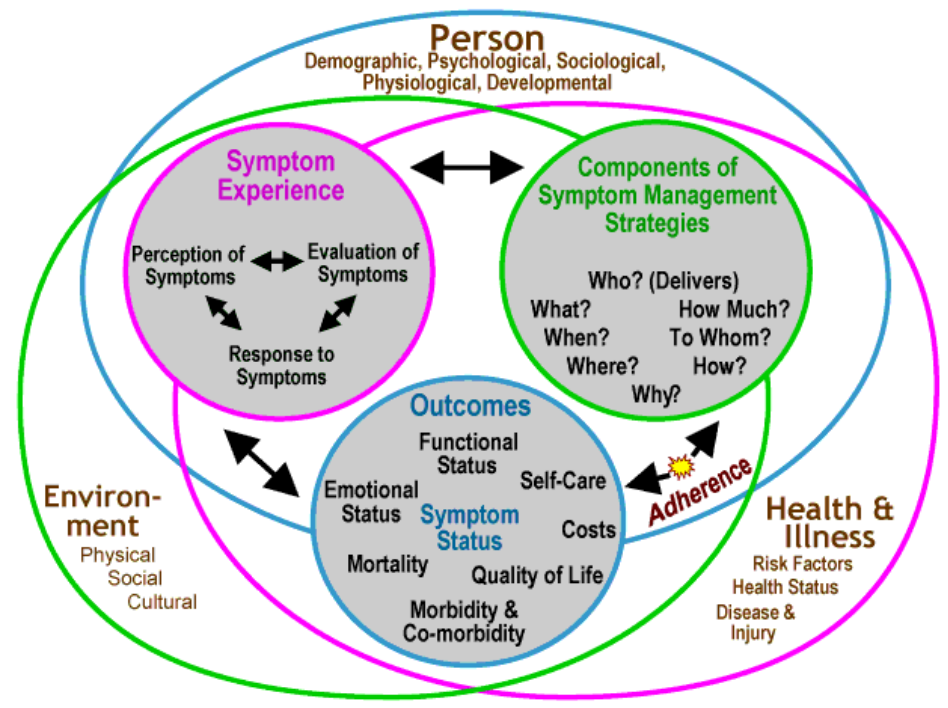

Figure 3 The Symptom Management Model.

Dodd M, et al (2001). Advancing the Science of Symptom Management. Journal of Advanced Nursing, 33(5), 668-676.

(Permission to reprint from Copyright Clearance Center's Rights Link service)

The SMT was developed to guide the assessment and management of symptoms in nursing practice, and to develop questions and hypotheses for nursing research (Smith 2014a, Dodd et al 2001). The goal of symptom management is to prevent or delay a negative outcome through biomedical, professional and management strategies in order to reduce the frequency, minimize the severity and relive the distress associated with cooccurring symptoms. The SMT is based upon the assumptions that the gold standard for studying symptoms is based on the individuals experience and his/her self-report. The theory acknowledges that people may need 
treatment or intervention, even though they have not yet experienced a symptom. The theory also proposes that all troublesome symptoms should be managed (Dodd et al 2001). The SMT has previously been used as a framework for designing, testing and evaluating symptom management strategies in several studies (Eller et al. 2005, Bentsen et al. 2013, Rosen et al. 2014, Newcomb 2010).

The SMT includes three of the central concepts in nursing, namely the person, health/illness and the environment. Each component of the model can be influenced by every other component as well as the domains, the person, health/illness status and the environment. The theory is based on the principle that to effectively manage any given symptom or group of symptoms, three symptom components must be considered, namely symptom experience, symptom management and symptom status outcome. Symptom experience includes the way a person perceives, interprets, evaluates, and reacts to a symptom, and the degrees of distress and intensity they perceive. Symptom experience has been assessed and described in all four papers in this thesis. Symptom Management includes what strategies or actions will be used, how they will be performed, and who will perform them (what, how and who). Symptom status outcome, the results of an intervention or treatment. One intervention might have an effect on more than one symptom. Outcome measures may involve changes of the symptom experience, quality of life, self-care ability, functional status or shorter hospital stay (Smith 2014a). Symptoms are known to be a good patient reported outcome that captures the patient's perspective on care and treatment (Cleeland 2007, Antunes et al. 2014). 
The use of patient-reported outcome has been found to improve care for patients through enhanced communication and management (Antunes et al. 2014).

In addition to the previous mentioned an additional concept is used in the thesis, namely "symptom burden". Zambroski and colleagues (2005) referred to symptom burden as the mean of the frequency, severity, and distress of a symptom (Zambroski et al. 2005), while Gapstur (2007) referred to symptom burden as "the subjective, quantifiable prevalence, frequency, and severity of symptoms, placing a physiologic burden on patients and producing multiple negative, physical, and emotional patient responses" (Gapstur 2007 p 673). In contrast to Gapstur's definition and in line with Zambroski et al. (2005), this thesis also includes the dimension of symptom distress in the description and calculation of symptom burden. In previous studies symptom burden has been associated with a reduced physical, psychological and social functioning as well as decreased healthrelated quality of life (Zambroski et al. 2005, Blinderman et al. 2008, Blinderman et al. 2009).

\section{Organizing care for people with multimorbidity}

People in the advanced stages of COPD are known to have a broad range of concurrent symptoms such as shortness of breath, lack of energy and cough (Blinderman et al. 2009, Bausewein et al. 2010, Jablonski et al. 2007). Older community-dwelling individuals with advanced chronic diseases are known to suffer from symptoms such as pain, lack of energy/fatigue, shortness of breath and loss of appetite (Wajnberg et al. 2013, Walke et al. 
2006). A lack of symptom control will result in significant deterioration of health-related quality of life and suffering (Newcomb 2010). Since there is no cure for COPD (Rabe et al. 2007) or other chronic diseases, symptom control is necessary for the improvement of people's health (Burgel et al. 2013).

A challenge for the health-care system is to organize and provide care that is individualized and focused on the whole person rather than fragmented parts (McEvoy and Duffy 2008). To manage a single chronic disease is difficult, but the situation is even more challenging when an older individual is diagnosed with several chronic diseases. Older people with manageable symptoms are more likely to feel safe, be in control and experience good health (Ebrahimi et al. 2013). A holistic approach could help health-care providers to identify resources and barriers to manage similar and unique symptoms that cause problems in the everyday life of people with chronic diseases. Older people have a tendency to report fewer symptoms compared to younger people (Goldberg et al. 2010) However, whether this is caused by the stereotypical belief that 'old age causes illness (Stewart et al. 2012) or whether in fact it is more difficult for older people to detect and interpretive symptoms (Riegel et al. 2010) is yet unknown.

Our current health- care organization is mostly based on a single disease model. In such a model, older people with multimorbidity tend to receive care that is fragmented, ineffective and unsafe, with polypharmacy and medication errors as a result (Paepe et al. 2013). This type of care often leads to higher health-care costs than necessary (Bergman et al. 1997). 
Health-care providers in the current health-care system might not be optimally prepared to take care of the multimorbid older patients. A stereotypical belief among health-care providers that old age equals illness has been shown to be associated with negative health outcomes for older people, and might lead to symptoms going undetected or being underreported (Stewart et al. 2012). When symptoms are not assessed and managed, people continue to suffer a reduced quality of life and a reduced functional status (Smith 2014a).

A novel approach that might be more effective to take care of older people with comorbidity is the Comprehensive Geriatric Assessment (CGA). CGA is defined as a "multidimensional interdisciplinary diagnostic process intended to determine a frail elderly person's medical, psychosocial and functional capabilities in order to develop an overall plan for treatment and long-term follow-up"(Rubenstein et al. $1991 \mathrm{p8s})$. Older people who are cared for in a CGA context have shown a higher survival rate and can more often return home after hospitalization compared with people receiving usual care (Ellis et al. 2011). A comprehensive evaluation of an older individual's health status requires a systematic assessment of variables such as physical, psychological, and socioeconomic factors. The efforts of the interdisciplinary team are required for efficient assessment, and special attention should be given to functional abilities, since these often indicate the need for health and social services (Kane 2013). Furthermore the use of protocols for care and management, implemented and acted on can provide a high degree of consistency (Ellis et al. 2011). 
In order to examine the costs and effects of care based on comprehensive geriatric assessment (CGA) provided by an ambulatory geriatric care unit (AGU), in addition to usual care, a single-centre randomized controlled trial was performed. The study was called The Ambulatory Geriatric Assessment - a Frailty Intervention (AGe-FIT) (Ekdahl et al. 2015). The study hypothesis of the Age-FIT was that the care based on CGA provided by an ambulatory geriatric outpatient clinic would reduce hospitalization (primary outcome) compared with usual care. The results showed that the care given by the ambulatory geriatric outpatient clinic based on CGA increased the elderly's sense of security, and reduced the days of inpatient hospital care compared to usual care; without increasing the health-care costs (Ekdahl et al. 2015). Secondary data regarding symptoms from this AGe-FIT study are included and presented in this thesis in papers II and IV.

As a part of the multidisciplinary team, nurses play an important role in assessment, optimizing care, and treatment of symptoms. As nurses take on more responsibilities for the care of people with both acute and chronic illnesses, the interest in improving symptom management has increased (Smith 2014b). A symptom is often what prompts a person to first contact a health-care clinic, usually after all self-management strategies have failed. According to the ICN Code of Ethics for Nurses (ICN), nurses are responsible for promoting health, preventing illness, restoring health and alleviating suffering. They have a key role in symptom management as they are involved in all stages of care and are often the first people that patients meet when they approach health-care (Fletcher and Dahl 2013). 
Older people are the largest group in need of care in hospitals, home care and in nursing homes. Nurses often manage various needs in older people with chronic diseases. One challenge in caring for these vulnerable older people is to recognize pathological changes and use resources to prevent, halt or overcome further decline (Kane 2013). 


\section{Rationale for the thesis}

Within the multidisciplinary team, nurses play an important role in preventing, easing or delaying negative consequences of the disease by optimal symptom management. This includes assisting older people to achieve an acceptable level of symptom relief (Smith 2014a). Symptom experience is not well described in the group of older people with multimorbidity, and there is a need for longitudinal studies assessing and describing changes of symptoms over time. Earlier research has shown that older people have a wide and sometimes unpredictable spectrum of responses to illness (Riegel et al. 2010). Therefore, there is a need for clinical trials that assess and evaluate symptoms in older people with multimorbidity, unfortunately they are often excluded from all types of clinical trials or studies (Zulman et al. 2011).

Symptom research has so far mostly been performed in a context of the most advanced stages of single diseases (Blinderman et al. 2008, Blinderman et al. 2009), or in people with an ongoing treatment for a severe disease (Knapp et al. 2012, Hofsø et al. 2013). Early recognition of and timely response to a chronic disease might lead to a more successful diagnosis and treatment (Vestbo et al. 2013, McMurray et al. 2012). However, symptom experience from a multidimensional perspective among people diagnosed with earlier stages of COPD (mild and moderate airflow limitation) is sparsely described in earlier research. 
It is known that a high symptom burden is associated with a decreased health-related quality of life (Santos-Eggimann et al. 2009, Newcomb 2010), higher health-care costs(Wolff et al. 2002, Condelius et al. 2007), and it often results in a high caregiver burden (Kuzuya et al. 2011). But how living with a high symptom burden is perceived by older people with multimorbidity has not previously been described in qualitative research. 


\section{AIMS}

The overall aim of the thesis was to describe different aspects of symptom burden from the perspective of community-dwelling people with chronic diseases.

Aim Paper I: The aim of this study was to describe the multidimensional symptom profile in outpatients with stable COPD and to determine whether the symptom experience differed between patients with moderate and severe airflow limitations.

Aim Paper II: The aim of this study was to describe the multidimensional symptom profile and symptom burden of community-dwelling older people with multimorbidity. An additional aim was to describe which factors are related to symptom burden.

Aim Paper III: The aim of this study was to explore the experience of living with a high symptom burden from the perspective of older communitydwelling people with multimorbidity.

Aim Paper IV: The aim of this study was to follow the symptom trajectory of community-dwelling older people with multimorbidity, and to explore the effect on symptom burden from an ambulatory geriatric care unit, based on comprehensive geriatric assessment. 


\section{METHOD}

\section{Design}

This thesis includes three quantitative studies and one qualitative study. An overview of the design and methods are shown below (Table 1).

Table 1. Overview of the design and methods of papers I-IV.

\begin{tabular}{|c|c|c|c|c|}
\hline & Design & Participants & Assessments & Data analysis \\
\hline Paper I & $\begin{array}{l}\text { Cross sectional } \\
\text { study, descriptive } \\
\text { and comparative }\end{array}$ & $\begin{array}{l}91 \text { Participants } \\
\text { with COPD, } \\
\text { moderate and } \\
\text { severe airflow } \\
\text { limitation }\end{array}$ & $\begin{array}{l}\text { MSAS, BMI, FEV1, SpO2, } \\
\text { Background characteristics } \\
\text { Self-reported } \\
\text { questionnaire, clinical } \\
\text { assessments, Data } \\
\text { collected 2007-2009 }\end{array}$ & $\begin{array}{l}\text { Cronbach's alpha test } \\
\text { Chi-square, Student's t-test, } \\
\text { Mann Whitney U test, }\end{array}$ \\
\hline Paper II & $\begin{array}{l}\text { Cross sectional } \\
\text { study, explorative } \\
\text { and descriptive }\end{array}$ & $\begin{array}{l}380 \text { participants } \\
\text { with } \\
\text { multimorbidity }\end{array}$ & $\begin{array}{l}\text { MSAS, GDS, MMSE, BMI, } \\
\text { Medical diagnoses, } \\
\text { Background characteristics } \\
\text { Protocol guided interview } \\
\text { Data collected } 2011\end{array}$ & $\begin{array}{l}\text { Cronbach's alpha test } \\
\text { Chi-square, Student's t-test, } \\
\text { Mann Whitney U test, Spearman } \\
\text { correlation, Multiple linear } \\
\text { Regression analysis }\end{array}$ \\
\hline Paper III & $\begin{array}{l}\text { Qualitative } \\
\text { descriptive }\end{array}$ & $\begin{array}{l}20 \text { participants } \\
\text { with } \\
\text { multimorbidity }\end{array}$ & $\begin{array}{l}\text { Qualitative face to face } \\
\text { interviews, MSAS, } \\
\text { Background } \\
\text { characteristics, } \\
\text { Data collected } 2013\end{array}$ & $\begin{array}{l}\text { Content analysis, } \\
\text { Descriptive statistics. }\end{array}$ \\
\hline Paper IV & $\begin{array}{l}\text { Secondary } \\
\text { analysis of data } \\
\text { in RCT, } \\
\text { Longitudinal } \\
\text { and compar- } \\
\text { ative }\end{array}$ & $\begin{array}{l}247 \text { Participants } \\
\text { with } \\
\text { multimorbidity }\end{array}$ & $\begin{array}{l}\text { MSAS, GDS, MMSE, } \\
\text { Medical diagnoses, } \\
\text { Background characteristics } \\
\text { Protocol guided interview } \\
\text { Data collected at baseline, } \\
12 \text { and } 24 \text { months between } \\
2011-2013\end{array}$ & $\begin{array}{l}\text { Cronbach's alpha test, } \\
\text { Chi-square, Student's t-test, } \\
\text { Mann Whitney U test. Repeated } \\
\text { measures Friedman ANOVA. } \\
\text { Wilcoxon related samples } \\
\text { signed-ranks test. Cochrans Q } \\
\text { test, McNemar's test }\end{array}$ \\
\hline
\end{tabular}

Abbreviations: MSAS; The Memorial Symptom Assessment Scale, BMI; Body mass index, FEV1; Forced expiratory volume in $1 \mathrm{~s}$, SpO2; Peripheral capillary oxygen saturation, MMSE Mini-Mental State Examination, GDS-15 Geriatric Depression Scale, ICD; International Classification of Disease COPD; Chronic Obstructive Pulmonary Disease, RCT 
Data for this thesis was collected systematically either by protocol guided interviews using validated questionnaires or by audio recorded qualitative interviews.

Paper (I) includes people diagnosed with COPD and was part of a larger cross-sectional study of 121 participants diagnosed with COPD. The main purpose of that study was to describe symptoms, function and health among patients with stable COPD.

Two subsequent papers in the thesis (II and IV) present data from the AGeFIT, (Ambulatory Geriatric Assessment - a Frailty Intervention) study. This was a randomized controlled trial aimed at preventing hospital readmissions and functional deterioration in high risk older adults. This RCT included 382 participants with multimorbidity. Data was assessed at baseline, 12 and 24 months. Paper III presents a qualitative study, with interviews from 20 participants included in the AGe-FIT study.

\section{Participants and Procedures}

Common to all participants included in this thesis was that all had been diagnosed with chronic disease and they were living at home. Most of the participants were older. In paper I all participants had been diagnosed with COPD (ICD-10 code J44). They were in a clinically stable condition with no change in medication for the previous four weeks and with no exacerbation. Participants were excluded if they had any other serious coexisting medical condition such as: other lung disease, rheumatoid arthritis, cancer within the last five years, severe ischemic heart disease, 
renal failure, liver disease, insulin-dependent diabetes, stroke, or multiple sclerosis, or other difficulties that might interfere with the assessments. Eligibility was determined through the patient administrative system in the pulmonary department at a university hospital and a county hospital. People who fulfilled the diagnostic criteria received a letter with information and an introduction to the study. One week later they were telephoned by a member of the research group, who provided additional information and obtained their verbal informed consent. People who were willing to participate were offered an appointment at the outpatient clinic for assessment.

Out of the 121 who participated in the main study, eight were not assessed for symptom experience. There were only a few participants classified with mild $(n=6)$ and very severe air flow limitation $(n=16)$ and therefor the analysis were only performed on a limited sample of 91 participants with moderate and severe air flow limitation. A flowchart of the inclusion and exclusion process of participants diagnosed with COPD and assessed in paper I is shown in (figure 4). Data were assessed between January 2007 and September 2009. 


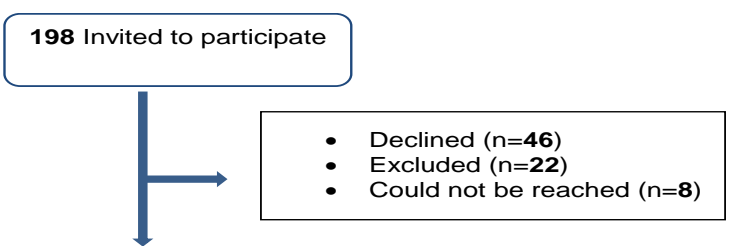

122 Participants accepted

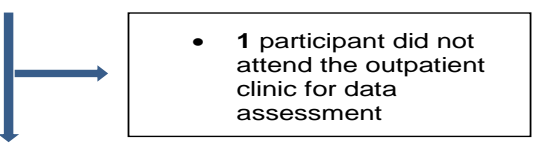

121 participants included in the main study

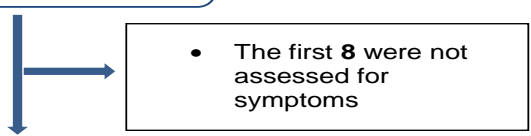

113 participants assessed with the MSAS

Excluded from the analysis paper (I) - Mild airflow limitation $(n=6)$

- very severe airflow limitation $(n=16)$

91 Participants included in paper (I)

- Moderate airflow limitations $(n=42)$

- Severe airflow limitations $(n=49)$.

Figure 4. Flow chart of the inclusion and exclusion process of participants diagnosed with COPD, paper I in this thesis 
The AGe-FIT study, included 382 community-dwelling elderly people living in their own homes (not in nursing homes), identified through the patient administrative system. Included were elderly ( $\geq 75$ years) who had been hospitalized three or more times during the previous 12 months and had $\geq 3$ diagnoses in their medical records according to the International Classification of Diseases (ICD-10). No exclusion criteria other than "living in a nursing home" at the time of inclusion were used. Data was assessed at baseline, 12 and 24 months A flow-chart of the inclusion and exclusion process of the participants in the AGe-FIT study is shown in (Figure 5).

Data for the AGe-FIT study was collected between February 2011 and December 2013 in a municipality in the southeast of Sweden that contained rural and urban areas, with approximately 130,000 inhabitants, $8.3 \%$ of whom were aged $>75$ years. Potential participants were identified using the Care Data Warehouse of Östergotland, a population-based administrative database maintained by the county council.

Eligible participants were randomly assigned to one of two groups based on a randomization master list using SPSS software (version 18.0). An invitation letter explaining the purpose of the study was sent to the identified older people. They were then contacted by telephone and further information on the study was provided. Those willing to participate were offered an appointment at their home for a protocol-directed interview by specially trained registered nurses or a registered occupational therapist. 


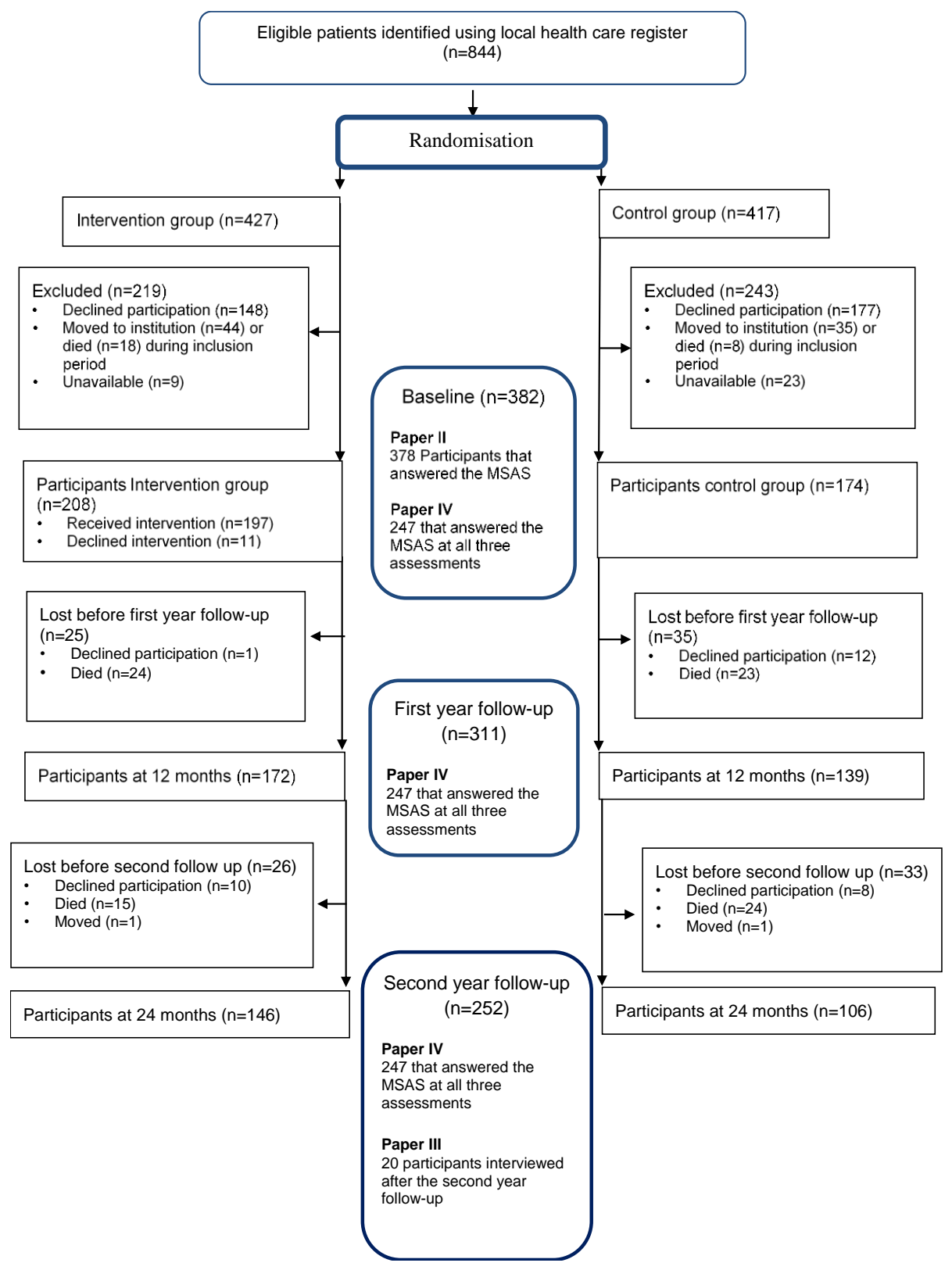

Figure 5. Flow chart of the inclusion, exclusion process and followup of the AGe-FIT main study. Papers II, III, IV is included in this thesis 
Participants in the intervention group (IG) received interdisciplinary care for 24 months (2011-2013) at an Ambulatory Geriatric Unit, (AGU), based on a comprehensive geriatric assessment (CGA) in addition to their usual care. Participants in the control group (CG) received usual care only.

Paper II presents data from the baseline assessment of the AGe-FIT and includes all 378 participants who completed the symptom assessment instrument in the first assessment Paper IV includes data from 247 community-dwelling older people who participated in all three assessments, at baseline, 12 and 24 months. Data were analysed, with 143 people assigned to the intervention group (IG) and 104 people assigned to the control group (CG). Of the total 382 participants included in the main study of the AGe-FIT, data of 135 participants was not included in the analysis of Paper IV since they did not participate in all three assessments. Rea-sons for not participating in all three assessments were: people had died $(64 \%)$, declined follow-up measurement (31\%), could not be reached or had moved from the city (5\%) after baseline or at the first year followup.

Paper III presents data from qualitative interviews with 20 participants from the AGe-FIT study. In this study a purposive sampling was used (Elo 2014). Participants who had reported a high scores on the Memorial Symptom Assessment Scale (MSAS) were selected from the second year follow-up of the AGe-FIT. Participants who fulfilled the inclusion criteria were invited with an information letter explaining the purpose of this study. 
In this study, a high score on the MSAS was $\geq 3$ on frequency, severity or distress in at least four prevalent symptoms. People who were willing to participate were offered a visit of the interviewer to their home. All interviews performed by JE between March and October 2013 and were all audio recorded.

\section{Intervention used in the AGe-FIT study}

After baseline assessment, participants in the intervention group (IG) were invited to receive care at the AGU. This was provided by a number of health-care professionals. Each participant had the opportunity to meet a nurse, a geriatrician, a municipal care manager, an occupational therapist, a physiotherapist, a dietician and a pharmacist. The CGA aimed to systematically identify, quantify, manage and evaluate the medical, psychological, and functional capabilities of the participant (Ellis et al. 2011). Initially, the CGA was based on a standardized procedure but was later personalized according to the patient's situation and needs. The frequency of the contacts between the participant and the clinic was dependent on the patient's own needs and wishes, and ranged from a few contacts per year for some to daily or weekly contacts for others. Symptoms were treated and documented according to clinical practice, and no standardized symptom instrument was used to assess or evaluate symptoms in day-to-day care. 
If participants were admitted to the hospital, the AGU team members visited them to provide further information to patients and staff, with the goal of facilitating care, discharge, and/or transfer to other types of care. Participants in the IG had, apart from the AGU, the same access to standard care as participants in the CG, which was the usual health and social care, i.e., health-care provided by the primary care, in- and outpatient hospital care, and social care.

\section{Data collection}

In papers I, II and IV data was collected by validated instruments, and data in paper III was collected by interview. The instruments used for the date collection in papers I, II and IV are valid, reliable and have prior to these studies been translated into Swedish and used in Sweden before. An overview of instruments used in this thesis is shown in (table 2). 
Table 2. Data collection and assessments

\begin{tabular}{lcccc}
\hline & COPD study & \multicolumn{2}{c}{ The AGe-FIT study } & \\
& & Baseline & 12 Months & 24 Months \\
& 2007-2009 & 2011 & 2012 & 2013 \\
\hline Symptoms, MSAS & $\mathrm{X}$ & $\mathrm{X}$ & $\mathrm{X}$ & $\mathrm{X}$ \\
Socio-demographic factors; Sex, age, & $\mathrm{X}$ & $\mathrm{X}$ & $\mathrm{X}$ & $\mathrm{X}$ \\
next of kin, current marital status, & $\mathrm{X}$ & $\mathrm{X}$ & $\mathrm{X}$ & $\mathrm{X}$ \\
smoking, BMI & $\mathrm{X}$ & $\mathrm{X}$ & $\mathrm{X}$ & $\mathrm{X}$ \\
Alcohol consumption vision, & & $\mathrm{X}$ & $\mathrm{X}$ & $\mathrm{X}$ \\
hearing, ICD diagnoses & & $\mathrm{X}$ & $\mathrm{X}$ & $\mathrm{X}$ \\
Physical and emotional health, from & $\mathrm{X}$ & & & \\
(ICF) check list. & & & & \\
FEV1 \% of predicted mean (SD) & $\mathrm{X}$ & & & \\
SpO2 \% mean (SD) & $\mathrm{X}$ & & & \\
Admitted to hospital previous year & $\mathrm{X}$ & & & \\
Exacerbation previous 6 months & $\mathrm{X}$ & & & \\
Medication use & $\mathrm{X}$ & & & \\
Depression, GDS-15 & & $\mathrm{X}$ & & $\mathrm{X}$ \\
Cognition MMSE & & $\mathrm{X}$ & & $\mathrm{X}$ \\
Qualitative interviews & & &
\end{tabular}

Abbreviations: MSAS; The Memorial Symptom Assessment Scale., BMI; Body mass index, FEV1; Forced expiratory volume in $1 \mathrm{~s}$, SpO2; Peripheral capillary oxygen saturation, MMSE Mini-Mental State Examination., GDS-15 Geriatric Depression Scale., ICD; International Classification of Diseases., ICF Checklist; Physical and emotional health International Classification of Functioning, Disability and Health check list.

\section{Background variables and participants characteristics}

In paper I data were collected on demographic and clinical data with regard to pulmonary disease. In papers II-IV demographic and clinical data also included questions about self-perceived poor vision or hearing. These data were collected by a protocol-guided interview. Weight and height were measured to calculate a BMI and all medical diagnoses were received from the Care Data Warehouse. 


\section{The Memorial Symptom Assessment Scale.}

In all four papers, symptoms were assessed using the Memorial Symptom Assessment Scale (MSAS) (Portenoy et al. 1994). MSAS evaluates a multidimensional symptom profile including the presence of 32 symptoms experienced during the preceding week. Symptoms were recorded as present (yes) or absent (no), and for 24 symptoms the dimensions of frequency ( $1=$ rarely to $4=$ almost constantly), were assessed. The severity (=slight to $4=$ very severe) and distress ( $0=$ not at all to $4=$ very much) were assessed for all 32 symptoms. Higher numbers indicate greater frequency, severity and distress. For clarity of reporting, the terms 'high frequency', 'high severity' and 'high distress' were used for the two highest scores of each symptom dimension.

One item dealing with sexual interest or activity was excluded from the original instrument in paper II and IV, leaving the instrument with 31 symptoms. The individual symptom burden score, i.e. MSAS symptom score, is the average of the three dimensions, or for the symptoms with two dimensions, the score was the average of the two dimensions. The MSAS produces four subscale scores: the overall physical symptom score (MSASPHYS), the mean score of 12 physical symptoms, the Psychological Symptom score (MSAS-PSYCH), the mean score of six psychological symptoms, the Global Distress Index (MSAS-GDI), the mean scores of the frequency scores for four psychological symptoms, and the distress score of six physical symptoms. The Total MSAS index score (TMSAS) is the average score for all 32 symptoms (Portenoy et al. 1994) or in papers II and IV for 31 symptoms. An overview of the MSAS subscales with the included 
items is shown below in Table 3. The MSAS was originally conducted to measure symptoms in people with cancer (Portenoy et al. 1994) but has since then been tested and evaluated in people with different chronic diseases (Tranmer et al. 2003, Blinderman et al. 2008, Blinderman et al. 2009). The MSAS is validated and has been used in a Swedish context (Browall et al. 2013, Pettersson et al. 2014). 
Table 3. Subscales and included items of the Memorial Symptom Assessment Scale

\begin{tabular}{|c|c|c|c|}
\hline $\begin{array}{l}\text { TMSAS } \\
\text { The mean score of all } \\
\text { symptom burden scores. }\end{array}$ & $\begin{array}{l}\text { MSAS-PHYS } \\
\text { The mean score of } \\
\text { the symptom } \\
\text { burden scores of; }\end{array}$ & $\begin{array}{l}\text { MSAS-PSYCH } \\
\text { The mean score of the } \\
\text { symptom burden } \\
\text { scores of; }\end{array}$ & $\begin{array}{l}\text { MSAS-GDI } \\
\text { The mean score of the } \\
\text { frequency }(\mathrm{F}) \text { of } 4 \\
\text { symptoms and the } \\
\text { distress }(\mathrm{D}) \text { in } 6 \\
\text { symptoms. }\end{array}$ \\
\hline Difficulty concentrating & & $\mathrm{x}$ & \\
\hline Pain & $\mathrm{x}$ & & (D) $x$ \\
\hline Lack of energy & $x$ & & (D) $x$ \\
\hline \multicolumn{4}{|l|}{ Cough } \\
\hline Feeling nervous & & $x$ & (F) $x$ \\
\hline Dry mouth & $x$ & & (D) $x$ \\
\hline Nausea & $x$ & & \\
\hline Feeling drowsy & $x$ & & (D) $x$ \\
\hline \multicolumn{4}{|l|}{$\begin{array}{l}\text { Numbness/tingling in } \\
\text { hands/feet }\end{array}$} \\
\hline Difficulty sleeping & & $\mathrm{x}$ & \\
\hline Feeling bloated & $x$ & & \\
\hline \multicolumn{4}{|l|}{ Problems with urination } \\
\hline Vomiting & $x$ & & \\
\hline \multicolumn{4}{|l|}{ Shortness of breath } \\
\hline \multicolumn{4}{|l|}{ Diarrhea } \\
\hline Feeling sad & & $x$ & (F) $x$ \\
\hline \multicolumn{4}{|l|}{ Sweats } \\
\hline Worrying & & $\mathrm{x}$ & $(F) x$ \\
\hline \multicolumn{4}{|l|}{$\begin{array}{l}\text { Problems with sexual } \\
\text { interest or activity }\end{array}$} \\
\hline Lack of appetite & $x$ & & (D) $x$ \\
\hline Dizziness & $x$ & & \\
\hline \multicolumn{4}{|l|}{ Difficulty swallowing } \\
\hline Feeling irritable & & $x$ & (F) $x$ \\
\hline \multicolumn{4}{|l|}{ Mouth sores } \\
\hline $\begin{array}{l}\text { Change in the way food } \\
\text { tastes }\end{array}$ & $x$ & & \\
\hline Weight loss & $x$ & & \\
\hline \multicolumn{4}{|l|}{ Hair loss } \\
\hline Constipation & $x$ & & (D) $x$ \\
\hline \multicolumn{4}{|l|}{ Swelling of arms or legs } \\
\hline \multicolumn{4}{|l|}{ "I don't look like myself" } \\
\hline Changes in skin & & & \\
\hline
\end{tabular}

Abbreviations: Symptom burden score is the mean of the dimensions Frequency, Severity and Distress, Total MSAS score (TMSAS), Physical Symptom Subscale score (MSAS-PHYS), Psychological Symptom Subscale score (MSAS-PSYCH), Global Distress Index (MSAS-GDI) 


\section{The Mini Mental State Exam}

In papers II and IV, cognition is reported. Cognitive decline was measured in this study by the Mini-Mental State Examination, (MMSE), MMSE is a 30-point brief questionnaire test that is used to screen for cognitive impairment; 24 points or more is considered as normal cognitive function; 18-23, mild-moderate cognitive dysfunction and $<18$ severe cognitive dysfunction. The MMSE has two parts, the first one covers orientation, memory, and attention, with a maximum score of 21 . This part requires vocal responses to questions such as -What is the year, season, date day and month?. The second part gives a maximum score of nine points and tests the ability to name, follow verbal and written commands, such as write a sentence spontaneously, and copy a complex polygon. The maximum total score is 30 (Folstein et al. 1975). The MMSE is one of the most widely used cognitive tests in community or primary care, and is one of the best test for ruling-out a diagnosis of dementia in a non-specialist care setting (Mitchell 2009).

\section{The Geriatric Depression Scale}

Risk of depression was reported on in papers II and IV and assessed with the Geriatric Depression Scale (GDS-15). The instrument has been shown to be reliable and valid and feasible also for people with a cognitive dysfunction (Conradsson et al. 2013). The GDS is a self-report measure of depression in older adults, with "Yes/No" answers. This shortened 15-item form is constructed from the 30 -item original instrument. The instrument does not take long to complete, approximately five to seven minutes, which makes it perfect for elderly people with a limited ability to concentrate for a long time. (Sheik and Yesavage 1986). 
The short form GDS 15 is recommended to be used in primary care and non- specialist settings to evaluate the risk of depression in late- life (Mitchell et al. 2010).

\section{Lung function}

To measure lung function (I) a dynamic lung function test was performed (Master Scope ${ }^{\circledR}$ Jaeger, Germany) in accordance with the ATS/ERS standardization (Brusasco et al. 2005). To calculate the percentage of predicted values for FEV1 and FVC, normative values from Hedenström et al. were used (Hedenstrom et al. 1985, Hedenstrom et al. 1986). The severity of airflow limitation was defined according to the Global Initiative for Chronic Obstructive Lung Disease (GOLD) grading system(Vestbo et al. 2013) as follows: GOLD 2: moderate airflow limitation 50\% $\leq$ FEV1, 80\% predicted, GOLD 3: Severe airflow limitation 30\% $\leq$ FEV1, 50\% predicted.

\section{Self-perceived physical and emotional health}

In paper I participants reported on self-perceived physical and emotional health during the previous month. Physical and emotional health was assessed with two questions from the International Classification of Functioning, Disability and Health check list (ICF) from the World Health Organization. The answer scores were from 5 -Very good to 1 -Very bad (WHO 2003). 


\section{Qualitative interviews}

Approximately one to three weeks after the second year follow up from the AGe-FIT study, the interviews for the qualitative study were performed. The MSAS from each participant's most recent data collection was used to guide the interview. The interviewer (JE) and the participant looked at the participants' last MSAS together and talked it through symptom by symptom.

Questions for the interview guide were based upon the three components from the theory of symptom management (Smith 2014a) symptom experience, -"Can you describe what this feels like"?, symptom management - "How do you manage this "? "Where did you learn to do that"? symptom status outcome. "Does that give you any relief"? The participants were also asked to describe what life was like, living with the concurrent symptoms and what consequences the symptoms had on their life.The interview guide was constructed by JE and $\mathrm{IH}$ and tested on one interview (Mitchell 2015). No changes in the interview guide were deemed necessary and the test interview was included in the analysis. The questions in the interview guide were open-ended. The opening question was -“Can you tell me about the symptom that is bothering you most right now". All interviews were performed by JE in the participant's home. The interviews were audio recorded and lasted from 20-54 minutes and all interviews were transcribed word-for-word. The confidentiality was provided by giving each interview transcript a code number (1-20), 


\section{Data analysis}

Categorical data are presented by frequencies and percentages, continuous data by means and standard deviations (SD) or median (min/max). The MSAS symptom burden scores are presented as mean (SD) for comparison with previous research, although most of the data are skewed. A Student's $\mathrm{t}$ - test was used to compare continuous data between the groups for normally distributed data, and a non-parametric Mann- Whitney U test for data that was skewed. A Chi-square test was used to compare categorical data (Field 2009).

In paper I, differences in symptom prevalence, experience and burden were compared between the participants with moderate and severe airflow limitations. Differences in symptom prevalence and symptom experience (frequency, severity and distress) between the two groups were analyzed by Chi-square or Fisher's exact test as appropriate(Field 2009), whereas differences in MSAS symptom burden score and MSAS subscales (MSASPHYS, MSAS-PSYCH, MSAS-GDI and TMSAS) were analyzed by using the Mann- Whitney U test (Field 2009). To avoid type 1 errors in the analysis when comparing groups in in this paper a choice was made to only report those items in the MSAS that were answered by $\geq 25 \%$ of the participants. P-values were two-sided, and the significance level was set at $\mathrm{p} \leq 0.05$. Statistical analyses were conducted using PASW Statistics (SPSS) version 20. The internal consistency of the TMSAS was evaluated by a Cronbach's alpha analysis (Polit 2013). 
Paper II was an explorative and descriptive paper presenting the symptom prevalence, experience and burden in a group of older people with multimorbidity. To determine independent associations between the subscale TMSAS and the background characteristics multiple linear regression analysis was used. The multiple model was built by entering those variables that had bivariate statistical significance with a $p \leq 0.05$ in the correlation, retaining those variables with $\mathrm{p} \leq 0.05$ in the final linear regression model. All two-way interactions were tested in the model. The significance level was set at $\mathrm{p} \leq 0.05$. Analyses were conducted using PASW Statistics (SPSS) version 20. The internal consistency of the TMSAS was evaluated by a Cronbach's alpha analysis (Polit 2013)

In paper IV symptom prevalence between the participants in the IG and participants in the CG was compared by Chi-square or Fisher's exact test as appropriate, while a Mann-Whitney $U$ test was used to analyze differences in the MSAS symptom burden score and subscales. Symptom trajectory was tested with Cochran's $Q$ test followed by McNemar's test for categorical data, or by non-parametric Friedman's ANOVA followed by Wilcoxon related samples signed-ranks test for continuous data (Field 2009). The significance level was set at $p \leq 0.01$ to correct for multiple testing and avoid type one errors (Field 2009). Analyses were conducted using PASW Statistics (SPSS) version 22. The internal consistency of the TMSAS was evaluated by a Cronbach's alpha analysis (Polit 2013). 
Paper III. Content analysis was used to analyze the data from the qualitative interviews, using the following steps (Graneheim and Lundman 2004).

1. The transcribed interviews were read thorough several times to get a deeper understanding of the whole with a focus on both the surface structure of the text and the underlying meaning asking the question, "What is this about?".

2. Significant text units (meaning units) were identified marked and labeled with open coding close to the participant's statements (Table 4).

3. Codes were then sorted and grouped into sub-themes depending on the content (Table 4).

4. During the analysis the sub-themes were grouped and re-grouped to identify significant similarities and differences, two sub-themes were merged into one.

5. The final structure consisted of three sub-themes and one overall theme.

Table 4: Example of the analysis process:

\begin{tabular}{lllc}
\hline Meaning unit & $\begin{array}{l}\text { Condensed } \\
\text { transcription }\end{array}$ & Sub-theme & Theme \\
\hline
\end{tabular}

$\begin{array}{llll}\text { Participant 19; My wife has to do } & \text { Don't have the } & \text { To feel } & \text { To adjust or } \\ \text { everything around here I just sit here ability to } & \text { inadequate and endure } \\ \text { and do nothing, the only thing I still } & \text { contribute } & \text { limited } & \\ \text { can achieve is to empty the dish- } & \text { anymore } & \end{array}$
washer

Examples of meaning units, from the analyses of total symptom burden in older people with multimorbidity 
The first author of the qualitative study, JE is a nurse with experience of clinical work in medical, surgical and ICU wards in hospital. During the study period with data collection and interviews, JE was never involved as a clinical nurse in the outpatient clinic in the AGe-FIT study. In order to ensure trustworthiness (Elo 2014, Graneheim and Lundman 2004) the credibility was established by using quotes referring to each theme and sub-theme. Dependability was established by the use of an interview guide and the same person, JE was involved in each step, from design, interview, analysis and writing the manuscript, with support provided by supervisors and co-author. Transferability was established by giving a close description of the participants in the group and providing descriptive statistical data (Polit 2013)

\section{Ethical approval and considerations}

Research that involves human beings must protect the participants' rights, which requires careful consideration by all researchers, data collectors or personnel involved in every step of a research study (Polit 2013). In both studies (COPD and AGe-FIT) the participants gave oral informed consent after they had received oral and written information, in the AGe-FIT study the participants also gave written informed consent at the time of the first data assessment (Polit 2013). Since the AGe-FIT study included old and sometimes very vulnerable people, special attention was given to their wellbeing during the data assessment. All data collections took place in the participant's own home (Gagnon et al. 2015). Interviewers were careful and showed respect when they entered the participant's private sphere. To answer all of the questions in the research protocol took time, and for some 
participants it took more time than for others. Data collectors had to be aware of the participant's health status and not push them to go on, but to do the opposite, and ask if they wanted to take breaks. The principal of respect for human dignity includes the right of self-determination of the study and to be treated with respect (Polit 2013). All studies in this thesis were performed in accordance with the declaration of Helsinki (WMA 2013). The studies were approved by the local research ethics committee, paper I: Dnr M 121-06, Paper II, IV: Dnr 2011/41-31, Paper III Dnr 2012/24432. 


\section{RESULTS}

\section{Background variables and characteristics}

The mean age of the participants in this thesis was 67.2 (7.6) in the COPD study and 82 (4.8) for the Age-FIT study at baseline. The distribution between men and women were almost equal for both studies COPD and Age-FIT, with exception for in the qualitative paper III where $80 \%$ were women. All participants were community dwelling and lived in their own home. Between $50-70 \%$ of the participants were married or cohabitating in the Age-FIT study and the COPD study. In the qualitative study the majority of the participants lived alone. (Table 5). 
Table 5. Background characteristics

\begin{tabular}{|c|c|c|}
\hline & $\begin{array}{l}\text { COPD } \\
\mathbf{N}=91\end{array}$ & $\begin{array}{l}\text { Age-FIT } \\
\mathrm{N}=378\end{array}$ \\
\hline Age (yrs.) mean (SD) & $67.2(7.7)$ & $82(4.8)$ \\
\hline Women n (\%) & $48(53)$ & $182(48)$ \\
\hline Lived alone $\mathrm{n}(\%)$ & $28(31)$ & $193(51)$ \\
\hline Employed n (\%) & $14(15)$ & \\
\hline Elementary school n (\%) & $52(57)$ & $305(81)$ \\
\hline Secondary school or higher education n (\%) & $28(31)$ & $68(18)$ \\
\hline Poor hearing with or without hearing device $\mathrm{n}(\%)$ & & $130(34)$ \\
\hline Poor vision with or without glasses, $\mathrm{n}(\%)$ & & $104(28)$ \\
\hline Smoking $\mathrm{n}(\%)$ & $25(28)$ & $32(8)$ \\
\hline Never smoked n (\%) & $3(3)$ & $155(41)$ \\
\hline Pack-yrs smoking mean (SD) & $31,7(17,0)$ & \\
\hline Physical health mean (SD) & $3.1(0.8)$ & \\
\hline Mental health mean (SD) & $3.6(0.9)$ & \\
\hline Admitted to hospital previous year n (\%) & $24(26)$ & \\
\hline BMI mean (SD) & $26.8(5.7)$ & $26.1(4.6)$ \\
\hline MMSE mean (SD) & & $26.3(3.2)$ \\
\hline MMSE score $20-24$ n (\%) & & $65(17)$ \\
\hline MMSE score $10-19 \mathrm{n}(\%)$ & & $12(3)$ \\
\hline MMSE score $\leq 9 \mathrm{n}(\%)$ & & 0 \\
\hline GDS score mean (SD) & & $3.7(3.0)$ \\
\hline GDS score $\geq 5 \mathrm{n}(\%)$ & & $120(32)$ \\
\hline \multicolumn{3}{|l|}{ Diagnosis according to ICD 10 Chapter } \\
\hline 01.Certain infectious and parasitic diseases (A00-B99) n (\%) & & $166(44)$ \\
\hline 02.Neoplasma (C00-D48) n (\%) & & $158(42)$ \\
\hline $\begin{array}{l}\text { 03.Diseases of the blood and blood-forming organs and certain disorders } \\
\text { involving the immune mechanism (D50-D89) } \mathrm{n}(\%)\end{array}$ & & $116(31)$ \\
\hline 04.Endocrine, nutritional and metabolic diseases (E00-E90) n (\%) & & $187(50)$ \\
\hline 05.Mental and behavioural disorders (F00-F99) n (\%) & & $127(33)$ \\
\hline 06.Diseases of the nervous system (G00-G99) n (\%) & & $130(34)$ \\
\hline 07.Diseases of the eye and adnexa (H00-H59) n (\%) & & $219(58)$ \\
\hline 08.Diseases of the ear and mastoid process (H60-H95) n (\%) & & $142(37)$ \\
\hline 09.Diseases of the circulatory system (I00-I99) n (\%) & & $362(96)$ \\
\hline 10.Diseases of the respiratory system (J00-J99) n (\%) & & $210(55)$ \\
\hline 11.Diseases of the digestive system (K00-K93) n (\%) & & $206(54)$ \\
\hline 12.Diseases of the skin and subcutaneous tissue (L00-L99) n (\%) & & $164(43)$ \\
\hline 13.Diseases of the musculoskeletal system and connective tissue (M00-M99) n (\%) & & $295(78)$ \\
\hline
\end{tabular}

Abbreviations: BMI: Body Mass Index, Pack yrs: Pack years, number of cigarettes a person has smoked over time. One pack year $=20$ cigarettes /day/year MMSE=Mini-Mental State Examination, Geriatric Depression Scale=GDS-15, ICD=International Classification of Diseases 


\section{Symptom burden}

The participants (III) from the AGe-FIT study described what it was like living with a high symptom burden. To these participants life was an endless struggle where you either had to adjust or endure to the current situation. To adjust or endure was interpreted as the overall theme in this study. One participant described it as "It is like my body and mind are not connected anymore and it is just awful". Their bodies were failing and the life they used to have was gone forever. The majority of the participants said that their fighting spirit or the will to take charge of their situation was gone. The main theme of this study was composed of three sub-themes; to feel inadequate and limited, to feel dependent, and to feel dejected (Figure $6)$.

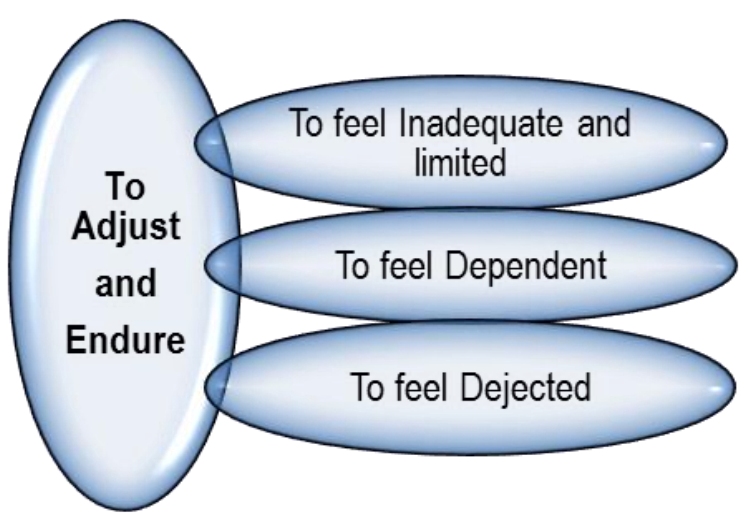

Fig 6. Theme and sub-themes of living with a high symptom burden. 
To feel inadequate and limited; the participants felt that they no longer had either the capacity or the ability to manage or control things. Things they had done with ease before were just not possible anymore, their bodies were "totally worn out" and they felt useless and inadequate. The psychological effects of living with a high symptom burden also caused emotional vulnerability.

To feel dependent; the participants could no longer manage things they did prior to the development of their high symptom burden. To be dependent on others to provide services was a new and inconvenient experience. The dependency caused much guilt especially towards children or partners. Not being able to manage on their own was often seen as a sign of weakness and the participants sometimes made jokes about it "You know I have just become lazy in old age" was quite a common expression.

To feel dejected; Participants expressed that it was hard to manage all the cooccurring symptoms. Some had given up hope and did not have the strength to try anymore. "In this old age you shouldn't expect so much out of life anyway", some said. A few of them said that they had lost their will to live. When the burden was too high the only thing left to do was to sit or lie down and wait for the episode to pass. The participants described a feeling of being unimaginably tired. The lack of energy was always present but there were episodes when it was even worse and there was just no way to handle it. 


\section{Factors related to symptom burden}

In the group of older people with multimorbidity a higher score on the subscale total symptom burden (TMSAS) was significantly related to being female $\left(r_{s}=-0.16\right)$, having poor vision $\left(r_{s}=-0.14\right)$, and poor hearing $\left(r_{s}=-\right.$ 0.10). A higher TMSAS was also related to having a risk of depression $\left(\mathrm{r}_{\mathrm{s}}=\right.$ 0.57), diseases of mental and behavioral disorders $\left(r_{s}=0.21\right)$, diseases of the digestive system $\left(r_{s}=0.16\right)$ and diseases of the nervous system $\left(r_{s}=0.11\right)$. In a multiple linear regression TMSAS was independently related to poor vision (beta $=-0.153)$, risk of depression $($ beta $=0.566)$, and diseases of the digestive system (beta $=0.109$ ). The $\mathrm{R}^{2}$ for this model was 0.38 , indicating that $38 \%$ of the variance of TMSAS could be explained by these three predictors. (II)

\section{Symptom burden assessed with the MSAS}

Among the participants with COPD the five symptoms rated with the highest symptom burden score for the total group of participants were shortness of breath, dry mouth, cough, difficulty sleeping, and lack of energy. Participants with a severe airflow limitation had a significantly higher symptom burden score for the symptom shortness of breath than those with moderate airflow limitation.

For the group of people with multimorbidity the five symptoms with the highest symptom burden were, pain, lack of energy, difficulty sleeping, numbness and tingling in hands and feet, and dizziness. Analyzing symptom burden from an individual perspective, pain and lack of energy were still the symptoms with the highest symptom burden, followed by difficulty swallowing and "I don't look like myself" (II). With regard to the 
trajectory of symptom burden the analysis showed that symptom burden was persistent and remained stable over the two year period. Among the ten symptoms with the highest prevalence, pain had the highest symptom burden score in all three assessments (Table 6).

Table 6 . The trajectory of the symptom burden score among the ten most prevalent symptoms among older people with multimorbidity. $(n=247)$

\begin{tabular}{|c|c|c|c|c|}
\hline Symptoms & $\begin{array}{l}\text { Baseline } \\
\text { Symptom } \\
\text { Burden }\end{array}$ & $\begin{array}{c}1 \text { Year } \\
\text { Symptom } \\
\text { burden }\end{array}$ & $\begin{array}{c}2 \text { Year } \\
\text { Symptom } \\
\text { burden }\end{array}$ & $\mathrm{P}$ \\
\hline & $\underline{\text { mean }} \underline{\mathrm{SD}}$ & $\underline{\text { mean }} \underline{\mathrm{SD}}$ & $\underline{\text { mean }} \underline{\mathrm{SD}}$ & \\
\hline Pain & $2.70 \quad 0.70$ & $2.80 \quad 0.66$ & $2.64 \quad 0.60$ & 0.03 \\
\hline Difficulty sleeping & 2.590 .69 & $2.70 \quad 0.68$ & 2.420 .63 & 0.15 \\
\hline Lack of energy & 2.550 .63 & $2.48 \quad 0.66$ & $2.57 \quad 0.71$ & 0.67 \\
\hline Feeling sad & $2.44 \quad 0.68$ & $2.41 \quad 0.74$ & $2.31 \quad 0.58$ & 0.04 \\
\hline $\begin{array}{l}\text { Numbness/tingling in } \\
\text { hands/feet }\end{array}$ & $2.43 \quad 0.74$ & $2.46 \quad 0.76$ & $2.37 \quad 0.68$ & 0.69 \\
\hline Dizziness & 2.320 .83 & $2.39 \quad 0.71$ & 2.320 .83 & 0.69 \\
\hline Dry mouth & $2.22 \quad 0.71$ & 2.320 .66 & $2.20 \quad 0.62$ & 0.07 \\
\hline Feeling drowsy & $2.08 \quad 0.68$ & 2.150 .57 & 2.120 .59 & 0.65 \\
\hline Swelling of arms or legs & $2.06 \quad 0.83$ & $2.10 \quad 0.70$ & $2.00 \quad 0.80$ & 0.43 \\
\hline Cough & $2.05 \quad 0.64$ & $2.17 \quad 0.60$ & $2.14 \quad 0.65$ & 0.83 \\
\hline
\end{tabular}

MSAS symptom burden score is the mean score of the dimensions, frequency, severity and distress, $\min 0.9$ - max 4.0. P refers the trajectory of symptom burden and significance level was set at 0.01 .

Participants in the IG reported a higher symptom burden on 'feeling sad' at baseline; however during follow-up there were no statistically significant differences between the IG and CG in 'feeling sad' or in other symptoms (IV). 


\section{Symptom experience}

The participants diagnosed with COPD (I) reported a variety of different symptoms with a mean number of 7.9 (4.3) per person for the total sample. There were no statistically significant differences in mean number of symptoms between the participants with moderate or with severe airflow limitations. The participants in the AGe-FIT study reported a mean number of 8.5 (4.6) symptoms per person at baseline; $30 \%$ of the participants reported 10 co-occurring symptoms or more, and only three participants $(0.8 \%)$ reported no symptoms at all. In the qualitative study, only people who had reported a high symptom burden score were included in the study. The mean number of symptoms in that sample was 12 (5.3) symptoms per person. Paper IV only reported on those participants who participated in all three assessments; the mean number of symptoms per person varied between 8.0-8.6 in the IG and 7.8- 8.1 in the CG but with no significant differences between the two groups.

\section{Symptom prevalence}

The five most common symptoms in the group of people diagnosed with COPD were shortness of breath (90\%), cough (65\%), dry mouth (65\%), lack of energy (55\%) and difficulty sleeping (52\%) (I). The most common symptoms from the AGe-FIT study were pain (67\%), dry mouth (51\%), lack of energy (50\%), numbness/tingling in hands/feet $(47 \%)$, and feeling drowsy (42\%) (II) (Table 7). These highly prevalent symptoms in this group of elderly were persistent and stayed high over the two-year period (IV). 
Table 7 Symptom prevalence in people diagnosed with COPD and among older people with multimorbidity.

\begin{tabular}{lrr}
\hline Symptoms & COPD & Age-Fit \\
& $\mathrm{n} 91$ & $\mathrm{n} 378$ \\
\hline & $\mathrm{N}(\%)$ & $\mathrm{N}(\%)$ \\
Difficulty concentrating & $22(24)$ & $74(20)$ \\
Pain & $40(44)$ & $253(67)$ \\
Lack of energy & $50(55)$ & $189(50)$ \\
Cough & $59(65)$ & $129(34)$ \\
Feeling nervous & $20(22)$ & $103(27)$ \\
Dry mouth & $59(65)$ & $193(51)$ \\
Nausea & $5(5)$ & $52(14)$ \\
Feeling drowsy & $42(46)$ & $158(42)$ \\
Numbness/tingling in hands/feet & $30(33)$ & $178(47)$ \\
Difficulty sleeping & $47(52)$ & $153(40)$ \\
Feeling bloated & $16(18)$ & $92(24)$ \\
Problems with urination & $10(11)$ & $104(28)$ \\
Vomiting & $1(1)$ & $14(4)$ \\
Shortness of breath & $82(90)$ & $149(39)$ \\
Diarrhea & $3(3)$ & $60(16)$ \\
Feeling sad & $19(22)$ & $138(36)$ \\
Sweats & $24(26)$ & $71(19)$ \\
Worrying & $30(33)$ & $136(36)$ \\
Problems with sexual interest or activity & $13(14)$ & \\
Itching & $14(15)$ & $118(31)$ \\
Lack of appetite & $8(9)$ & $69(18)$ \\
Dizziness & $26(28)$ & $156(41)$ \\
Difficulty swallowing & $10(11)$ & $54(14)$ \\
Feeling irritable & $25(27)$ & $85(23)$ \\
Mouth sores & $12(13)$ & $42(11)$ \\
Change in the way food tastes & $6(6)$ & $43(11)$ \\
Weight loss & $3(3)$ & $28(7)$ \\
Hair loss & $4(4)$ & $19(5)$ \\
Constipation & $3(3)$ & $79(21)$ \\
Swelling of arms or legs & $3(15)$ & $130(35)$ \\
"I don't look like myself." & $11(12)$ & $102(27)$ \\
Changes in skin & &
\end{tabular}


Pain was the symptom with the highest prevalence in the group of elderly participants in the AGe-FIT study, and pain increased slightly over the two-year period. The pain trajectory showed that for some participants the presence or absence of pain changed over time and they did not report pain in every assessment, while others reported a more constant presence of pain. Out of the total 170 participants who reported pain at baseline, 128 (75\%) also reported pain at the second year follow-up. Twenty participants out of 247 did not report pain at all in the three assessments (Figure 7).

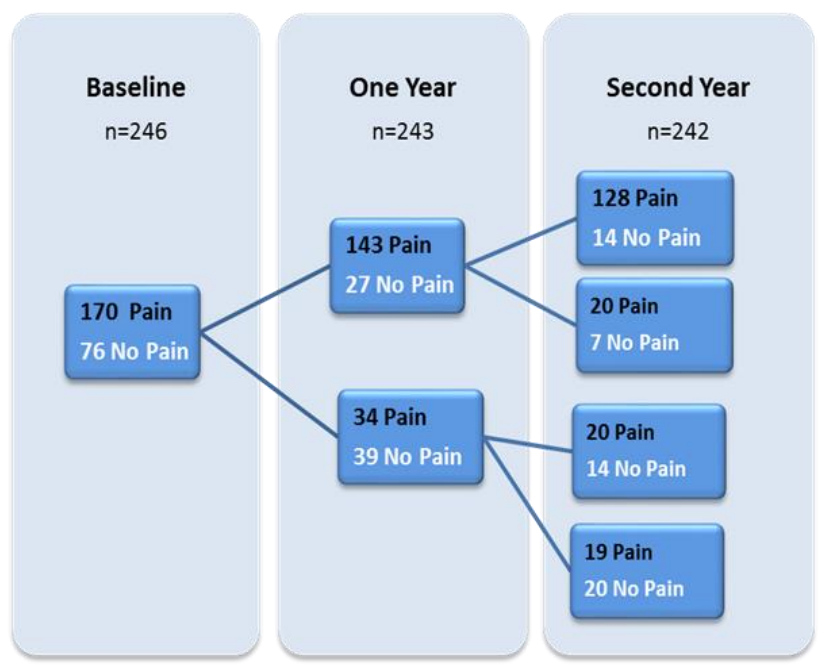

Figure 7. The pain prevalence trajectory from the AGe-FIT study. People that had or did not have pain over the period of two years. 


\section{High Symptom Frequency}

In the total group of participants diagnosed with COPD almost six out of ten participants (59\%) reported shortness of breath frequently (or almost constantly. Other symptoms that frequently occurred in people diagnosed with COPD were cough, dry mouth, difficulty sleeping and lack of energy (Table 8). People diagnosed with severe airflow limitation reported that shortness of breath and lack of energy occurred more frequently than people with moderate airflow limitation (I).

Table 8. High symptom frequency, severity and distress in people diagnosed with COPD (n 91)

\begin{tabular}{lrrr}
\hline $\begin{array}{l}\text { symptoms } \\
\text { symost prevalent }\end{array}$ & $\begin{array}{r}\text { High } \\
\text { Frequency } \\
\mathrm{n}(\%)^{\text {a }}\end{array}$ & $\begin{array}{r}\text { High } \\
\text { Severity } \\
\mathrm{n} \mathrm{( \% )}\end{array}$ & $\begin{array}{r}\text { High } \\
\text { Distress } \\
\mathrm{n}(\%)^{\mathrm{c}}\end{array}$ \\
\hline Shortness of breath & $54(59)$ & $25(27)$ & $43(47)$ \\
Cough & $27(30)$ & $9(10)$ & $13(14)$ \\
Dry mouth & $39(43)$ & $26(28)$ & $19(21)$ \\
Lack of energy & $25(28)$ & $13(14)$ & $23(25)$ \\
Difficulty sleeping & $31(34)$ & $16(18)$ & $24(26)$ \\
Feeling drowsy & $16(18)$ & $5(6)$ & $10(11)$ \\
Pain & $24(26)$ & $10(11)$ & $24(26)$ \\
Numbness/tingling in hands/feet & $13(14)$ & $6(7)$ & $10(11)$ \\
Worrying & $7(8)$ & $4(4)$ & $9(10)$ \\
Feeling irritable & $6(7)$ & $3(3)$ & $4(4)$ \\
\hline Percentage
\end{tabular}

Percentage of people with the symptom reporting a high frequency $=$ "frequently" or "almost constantly." b Percentage of people with symptom reporting high severity = "severe" or "very severe." c Percentage of people with the symptom reporting a high distress "quite a bit" or "very much." 
Among older people with multimorbidity, pain was the symptom reported with the high frequency score, with four out of ten participants (43\%) reporting that the symptom had occurred frequently or almost constantly during the preceding week. Except for pain also, lack of energy, dry mouth, numbness/tingling in hands/feet and difficulty sleeping were reported to occur frequently to almost constantly by $24-32 \%$ (II). In the total group of 247 participants from the AGe-FIT study who participated in all three assessments no statistically significant differences in symptom trajectory regarding high frequency over the two year frequency were found (Table 9).

\section{High Symptom Severity}

Among the ten most prevalent symptoms in the total group of participants diagnosed with COPD dry mouth, shortness of breath and difficulty sleeping were the three symptoms reported as most severe (table 8). Among these three symptoms no significant differences were found between the participants with moderate and severe airflow limitations (I).

Among older people with multimorbidity, pain was a symptom that most participants reported as severe. One-third (31\%) of the participants gave pain a high severity score (severe or very severe). Other symptoms reported with high severity scores were difficulty sleeping and lack of energy; these were reported as severe by $17-21 \%$ respectively (II). Data on the trajectory of the high severity scores showed no significant change over time in any of the assessed symptoms. 
The symptom reported to be most severe was pain followed by lack of energy and difficulty sleeping (Table 9). No significant difference regarding high severity scores was found between the IG and the CG in the AGe-FIT study (IV).

\section{High Symptom Distress}

Among the most prevalent symptoms, shortness of breath was rated as 'quite a bit' or 'very much' distressing by almost $50 \%$ of the participants diagnosed with COPD. Difficulty sleeping, pain and lack of energy were reported by one fourth of the total group (Table 8). Participants with severe airflow limitation reported significantly more distress regarding lack of energy than those with moderate airflow limitation (I).

For older people with multimorbidity pain and a lack of energy were reported with a high symptom distress score (quite a bit or very much distress) by $31 \%$ and $21 \%$ respectively (II). With regard to the trajectory of high distress among the ten most prevalent symptoms five symptoms were reported with significantly higher scores in the one year follow-up, namely, pain, dry mouth, numbness/tingling in hands/feet, difficulty sleeping and swelling of the arms or legs (Table 9). 


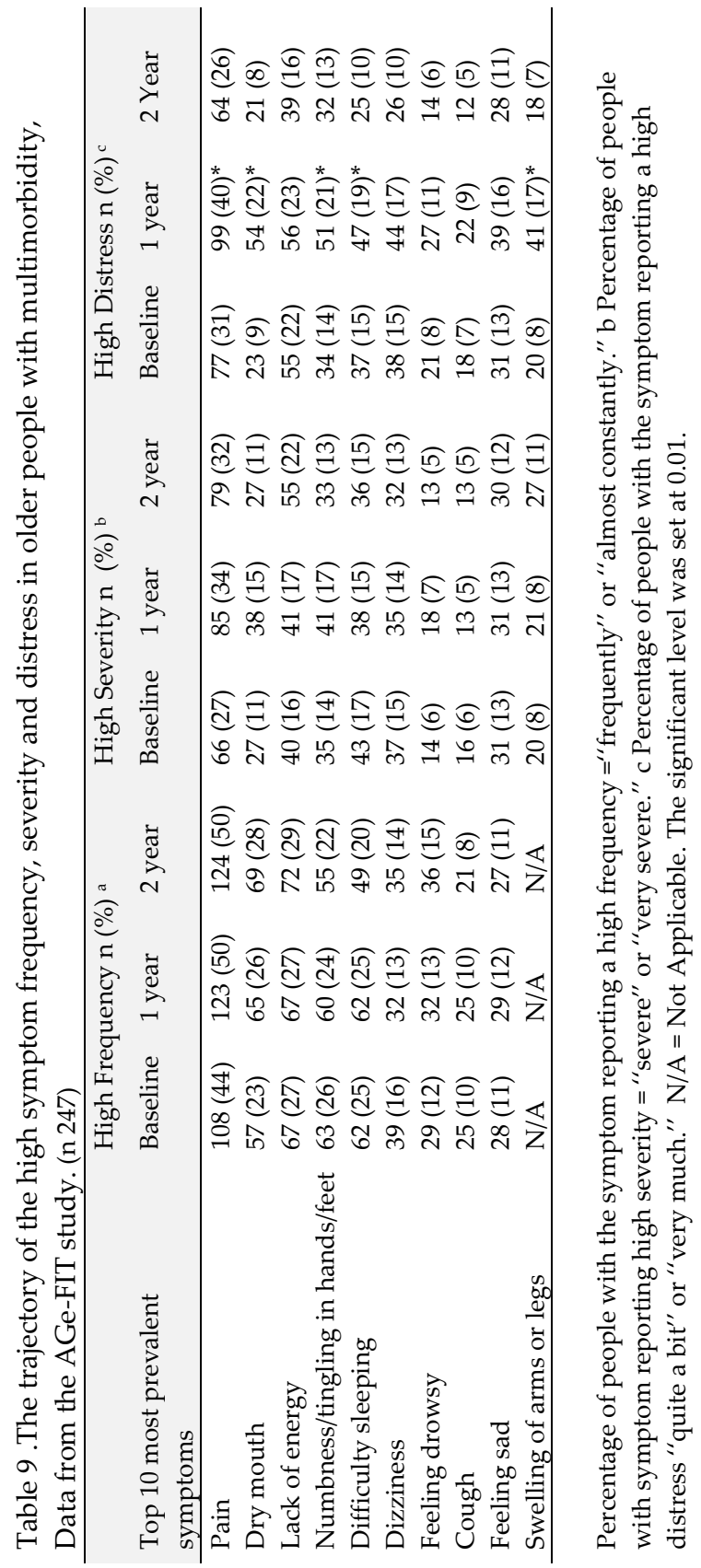


Table 10. MSAS subscale scores of people diagnosed with COPD and older people with multimorbidity

\begin{tabular}{lll}
\hline MSAS Subscales & $\begin{array}{l}\text { COPD }(\mathrm{n}=91) \\
\text { Median }(\mathrm{min} / \mathrm{max})\end{array}$ & $\begin{array}{l}\text { Age-FIT }(\mathrm{n}=378) \\
\text { Median }(\mathrm{min} / \mathrm{max})\end{array}$ \\
\hline MSAS-PHYS & $0.55(0.0 / 1.97)$ & $0.63(0.0 / 2.74)$ \\
MSAS-PSYCH & $0.45(0.0 / 2.87)$ & $0.56(0.0 / 3.83)$ \\
MSAS-GDI & $0.68(0.0 / 2.56)$ & $0.79(0.0 / 3.42)$ \\
TMSAS & $0.53(0.0 / 1.93)$ & $0.58(0.0 / 2.57)$ \\
\hline
\end{tabular}

Abbreviation: MSAS-PHYS: The overall physical symptom score, MSAS-PSYCH: Psychological Symptom score, MSAS-GDI: The Global distress index, TMSAS; Total MSAS index score.

\section{MSAS subscale scores}

Among the participants diagnosed with COPD the median subscale score ranged from 0.45, MSAS-PSYCH to the highest MSAS-GDI of 0.68 (Table 10). No significant differences were found between people with moderate and severe airflow limitations regarding any of the MSAS subscales (I). In the group of participants with multimorbidity, the median subscale score ran between 0.56 MSAS-PSYCH and 0.79 for the MSAS-GDI. For the group of elderly people with multimorbidity the analysis showed that the trajectory of the subscale score did not change significantly over time and none of the MSAS subscale scores differed between the IG and the CG (IV). 


\section{DISCUSSION}

\section{Discussion of the results}

People with chronic disease suffer from a variety of co-occurring and persistent symptoms, even in an earlier stage of the disease. Approximately half of the study populations reported general symptoms such as pain, lack of energy and dry mouth. Pain was especially burdensome for the older study population with multimorbidity. Shortness of breath and cough, two disease-specific symptoms were found to be particularly burdensome for people with COPD. The high symptom burden had a negative impact on the participants' life. They referred to it as an existence where they either had to adjust or endure, and life as they knew it had ceased to exist.

The high symptom burden as described in this thesis calls for improved symptom management. The SMT proposes that all troublesome symptoms should be assessed and managed (Dodd et al 2001). The broad range of concurrent symptoms and a significant symptom burden for a variety of symptoms in each paper of this thesis can be defined as high symptom burden. The symptom burden was also found to be persistent, since the result shows that symptom burden was as high at the beginning of the AGe-FIT study as at the end of the two-year period. The participants described that symptom burden affected their capacity in physical, psychological and cognitive ways and made them feel inadequate and 
limited, and dependent on others for support. This description of symptom burden is in line with Gapstur's (2007) definition of the concept "the subjective, quantifiable prevalence, frequency, and severity of symptoms placing a physiologic burden on patients and producing multiple negative, physical, and emotional patient responses "(Gapstur 2007 p 673).

Living everyday life with a high symptom burden was described as being hard to manage. The lack of capacity caused the participants much stress, living with multimorbidity requires adaptation to a stressful situation. The high symptom burden made it difficult for the participants to make plans. Not being able to plan activities and socialize with friends made the participants feel isolated and lonely. Similar findings were found in a study of older people with heart failure, where the impact of unpredictable symptoms led to a rather isolated existence (Aldred et al. 2005).

The participants often referred to their old age as the source of their high symptom burden rather than their many diseases. This confirms earlier findings from a qualitative study in people with multi-morbidity aged over 80, where participants blamed their increasing health problems such as pains, sleeplessness and problems with balance, mobility, eyesight, hearing and memory loss on the deterioration of their body due to old age (Elias and Lowton 2014). A stereotypical belief that 'old age causes illness' has been shown to be associated with negative health outcomes for older people, but this way of thinking is unfortunately often reinforced by health care professionals (Stewart et al. 2012, Cameron et al. 2010). 
The symptom burden limited several aspects of the participants' lives and made them unwillingly dependent on others. Feeling to be such a burden to others made them feel guilty. These findings confirm earlier findings that physical deterioration and increasing dependency were major concerns of the subjects and to maintain control was of the highest importance (Waterworth and Jorgensen 2010). To feel like a burden to others has previously been shown to be associated with depression and loss of dignity, and the will to live, near the end of life (Chochinov et al. 2005).

Living a daily life with a high symptom burden caused an emotional vulnerability. The participants described a burden of feeling sad, nervous, irritable and worried; feelings they usually could not understand or explain. The most vulnerable older people are often referred to as "frail older people". Frailty is a multidimensional geriatric syndrome involving loss of reserves (energy, health, physical ability and cognition,) (Rockwood et al.2005), and this could be a good description of some of the participants in this thesis. The participants said that living with a high symptom burden was very tiring; it was considered a too great of an effort to even try to do anything about their situation. Lack of energy or fatigue have been shown to be highly prevalent symptoms among people with chronic diseases (Theander et al. 2014).These are symptoms with an impact on cognitive, physical and psychosocial functioning in the everyday lives of older people with heart failure and COPD (Theander and Unosson 2004, Aldred et al. 2005). 
Living with a high symptom burden causes unpredictability in daily life, since the burden of symptoms quickly could increase. However, managing all kinds of stressors or threats against health in old age requires personalized care and consideration of contextual factors, rather than merely treating one symptom or diagnosis at a time (Black et al. 2013). Older people with multimorbidity are a complex and vulnerable group (Singer et al. 2011), with needs that are not met by our current health care system. These findings indicate that the symptom burden affects the whole life of these older people, and implementation of a holistic approach to determine both medical and psychosocial needs (Wieland 2003) might be beneficial, since it could lower the symptom burden. It is known that older people attach great importance to not complaining and they do not like to bother others with their problems (Elias and Lowton 2014). Therefor a direct approach of asking about concrete symptoms might be to prefer in order to grasp the full symptom burden.

The total symptom burden was independently associated with poor vision, likelihood of depression and diseases of the digestive system. Earlier studies have confirmed the association between depression and pain (Landi et al. 2005). If recognized and treated, depression is often reversible, but left untreated, depression may result in the onset of physical, cognitive, functional, and social impairment, as well as decreased quality of life, (Marc et al. 2008) and higher risk of mortality (Royall et al. 2007). The independent relationship between poor vision and the total symptom burden score has not previously been described, but studies have reported that people with poor hearing or vision are more likely to experience 
disability, and that there are associations between poor vision, poor hearing and depression (Huang et al. 2010). Previous studies have shown that people with diseases of the digestive system have a lower healthrelated quality of life (Simren et al. 2006, Frank et al. 2002) and that the severity of the gastro intestinal symptoms and health related quality of life are associated (Simren et al. 2006). In order to reduce the total burden the impact of concurrent symptoms must be recognized in clinical practice.

Among the participants in the Age-FIT pain, lack of energy, feeling sad, difficulty sleeping and numbness/tingling in hands/feet were all highly prevalent and persistent symptoms. There is a paucity of research addressing the prevalence and management of concurrent symptoms and symptom burden in older people with multimorbidity, and even less is known about possible interactions between these symptoms or how they cluster. Although, this is a frequent and well-known clinical problem, guidelines on symptom management for this population are lacking, for almost all other symptoms except for pain (Combs et al. 2013). With a growing number of older people living at home there is a need for clinical practice guidelines to support symptom management (Boeckxstaens and De Graaf 2011).

To older people with multimorbidity, pain was the symptom reported with the highest frequency, severity, and distress. Pain was a common symptom in our studies as in others almost seven out of ten participants from the AGe-FIT study and four out of ten in the group of people diagnosed with COPD had experienced pain during the preceding week. Persistent pain is 
highly prevalent in older people, although it is not a natural part of aging (Kaye et al. 2014). Persistent pain has a high impact on psychological wellbeing, resulting in a higher anxiety level and lower quality of life (Tse et al. 2013). Pain is also known to lead to limitation of physical activity and to a cycle of restriction, decreased participation, and greater disabilities, and it often overlaps with symptoms of depression (Molton and Terrill 2014). Although the location of pain was not registered in this thesis the most common sites of pain in older people are known to be located in the back, neck, leg/knee or hip and other joints (Abdulla et al. 2013). Specific sites for COPD-related pain are localized to the neck and trunk and interfere with daily activities (HajGhanbari et al. 2012). A systematic review showed that pain was a significant clinical problem for people diagnosed with COPD. Pain was experienced more by people diagnosed with COPD than by healthy people of similar age, and it was more predominant in earlier stages of COPD (van Dam van Isselt et al. 2014).

Previous studies have reported that pain is often underdiagnosed and undertreated in older people with multimorbidity (Abdulla et al. 2013, Kaye et al. 2014, Landi et al. 2001). Sometimes older people do not discuss or mention pain when consulting their health care provider, thinking that pain is a natural part of aging (Kaye et al. 2014). Independently of clinical diagnosis, $25 \%$ of older people do not receive analgesic treatment for pain, and people older than 85 are even less likely to receive analgesic treatment (Landi et al. 2001). Unresolved pain may lead to; difficulty with sleep, depression, anxiety, social isolation, cognitive dysfunction, malnutrition, and a decreased quality of life (Kaye et al. 2010). There has been a lack of 
age-specific management guidelines for geriatric pain, and health-care providers have felt that multimorbidity complicates appropriate management (Rastogi and Meek 2013). However, new guidance for treating pain in the elderly was published in 2013 (Abdulla et al. 2013). To manage pain, a comprehensive assessment is recommended involving a multidisciplinary approach with the appropriate use of various treatment alternatives with both pharmacotherapy, and interventional procedures such as physical rehabilitation, and psychological support (Kaye et al. 2014, Abdulla et al. 2013).

The main outcomes from the AGe-FIT study showed that interdisciplinary care at an AGU, based on CGA, reduced days in hospital and increased the participants' sense of security in care interaction without increasing costs (Ekdahl et al. 2015). It did not reduce symptom prevalence or symptom burden. There might be several explanations for why no effect of the intervention on symptoms was found. First, symptoms were not the main outcome of this study, and the AGU health-care providers did not target specific symptoms in day-to-day care at the clinic.

Secondly, the lack of effect of the intervention on the burden of symptoms might be related to underreporting of symptoms by the elderly to the clinician. It has been suggested that old age might cause an age-related response shift in symptoms that causes older people to respond and report symptoms differently than younger people (Ritchie et al. 2014, Riegel et al. 2010). 
However, health-care providers have the responsibility to give each person optimal support and symptom relief (Dodd et al 2001). The use of a multidimensional symptom instrument in clinical care might have helped to address that issue. The SMT states that the goal of symptom management is to prevent or delay a negative outcome through biomedical, professional and management strategies in order to reduce the frequency, minimize the severity and relieve the distress associated with all co-occurring symptoms (Smith 2014a, Dodd et al 2001). To implement a systematic approach with a symptom instruments in day- to- day- care could be time consuming. However, a simple self-administered questionnaire with follow-ups by telephone might be feasible (Ornstein et al. 2013). The use of a self-administered questionnaire has been studied with older cognitively healthy adults as well as with persons with mild cognitive impairment, and has been found to be promising (Beauchet et al. 2014). Another method self-administered symptom assessment could be to development a digital form for easy communication that is accessible for this group of older people. A tablet or smartphone could serve to facilitate more frequent gathering of health and functional information, and to provide interactive feedback on the responses entered by the elderly (Beauchet et al. 2014).The use of protocols implemented and acted on with a high degree of consistency has been shown to be beneficial in a CGA context (Ellis et al. 2011). The systematic use of repeated symptom assessments combined with symptom management has been shown to reduce symptom burden for community-dwelling people receiving palliative care (Ornstein et al. 2013). 
A routine of a broad assessment of symptoms and symptom burden (not restricted to the disease-specific burden) might lead to better symptom management (Sheppard et al. 2013, Chaudhry et al. 2013) which could maintain independence and functional ability, and sustain or improve quality of life for people with chronic diseases.

\section{Methodological considerations}

\section{Validity Reliability and Trustworthiness}

This thesis is based upon four papers using both quantitative and qualitative data in order to better understand different aspects of symptom experience and symptom burden in people with chronic disease (Polit 2013). The use of different research designs and several methods in this thesis strengthen the results (Polit 2013).

Although the studies were planned with great care, there are several methodological aspects that need to be considered, such as limitation in method of data assessment, statistical analysis, credibility, generalizability and transferability. First concerning the data assessment. In this thesis the MSAS instrument was used to explore the multidimensional symptom profile and symptom burden. The MSAS covers three of the symptom dimensions previously described by Lenz (Lenz et al. 1997), frequency, severity and distress. However the fourth dimension "quality" had to be assessed in another way. The qualitative dimension was assessed by interviewing the older people from the Age-FIT and by doing so the full multidimensional symptom profile was completed regarding the total 
symptom burden. The result of the qualitative study can help the reader to fully grasp the meaning of the high score of the quantitative data, reported with the MSAS instrument thereby strengthening the result of this thesis.

The MSAS has previously been shown to be a valid and reliable measure for assessing a multidimensional symptom profile in a Swedish-speaking context, both for research and in clinical practice, even though the original instrument was developed in a different language and for a different culture (Browall et al. 2013). However, validation of the MSAS performed by Browall and colleagues (Browall et al. 2013) was performed in a younger population of postmenopausal women diagnosed with breast cancer. The participants in that study were in the same age range as the COPD study in this thesis, but they were younger than the people included in the AgeFIT study. Browall and colleagues concluded that the MSAS instrument took approximately ten minutes to complete for the participants in their study, and MSAS is intended to be used for a self-report. However, the MSAS instrument has a large number of items, all with two or three dimensions (Portenoy et al. 1994), and in our study the instrument required much energy from the participants and was quite time consuming to answer for some of the older people with multimorbidity. In order to facilitate the respondent burden in the Age-Fit study all data were assessed by protocol-guided interviews. By using this method of collecting data we may have increased the risk that their symptom experience or burden was underestimated, since it is known that when questionnaires are administered by an interviewer, the scores tend to be lower. This is 
something that should be taken into consideration when scores are interpreted (Wajnberg et al. 2013, de Waal et al. 2012).

Another point to consider in our measurement is that MSAS was slightly adapted in the Age-FIT study which might have had consequences for the content validity of the instrument (Polit 2013). The original instrument contained 32 different items, however, in the AGe-FIT, one symptom dealing with sexual interest or activity was removed. During the first few protocol-directed interviews for the AGe-FIT study, there were some negative reactions from the participants on this specific item. After this the item was removed, leaving the instrument with 31 symptoms. This adaption did not have direct consequence for the calculation of the subscales. The MSAS subscales were calculated according to the guidelines of the original instrument, and the item problems with sexual interest or activity were not included in those subscales. This leaves us to conclude that the removal of the item did not affect the construct validity of MSAS (Polit 2013). Other studies sometimes add disease-specific symptoms relevant for their study, leaving the instrument with 35-36 items (Blinderman et al. 2008, Blinderman et al. 2009). However the inconsistent numbers of items (even with the same symptom instrument) in different studies makes it difficult to compare the mean symptoms per person.

With regard to the statistical analysis, there are some issues to consider. The type of statistical analysis used was chosen dependent on the sample size, distribution and level of the data (Field 2009). Since data collected with the MSAS was not normally distributed, non- parametric analysis was 
performed. However, in order to compare the symptom burden score with other studies using the same instrument these results were presented with mean (SD) (Blinderman et al. 2008, Blinderman et al. 2009, Zambroski et al. 2005). To avoid Type 1 errors from multiple testing, different strategies were used in different papers, dependent on the size of the study sample. In paper I only results for symptoms experienced by at least $25 \%$ of the participants were reported. In paper IV the significance level was set at 0.01 .

Trustworthiness in the preparation phase of the qualitative study was created by carefully planning the first interview. Much thought was given to the wording of the questions in the interview guide so they would be easily understood by the older people included in the study (Mitchell 2015). Since the participants had recently participated in the assessment of quantitative data with MSAS, the area of interest (symptoms) was familiar to them. The first interview were transcribed and scrutinized by one of the co-authors, I $\mathrm{H}$ in order to further develop the interview skill. One important skill in interviewing is to allow periods of silence (Mitchell 2015). It became clear that by letting the participant have a moment to reflect on the question they could provide a meaningful answer.

During the analysis of the qualitative data, several steps were taken in accordance with Graneheim \& Lundman (2004). The original transcriptions of the interviews were read through several times, and similarities that emerged were marked and coded, and eventually themes and sub-themes were created (Graneheim and Lundman 2004, Morse 
2008). The research questions were clear to all people involved in this study, from the construction of the interview guide and all the way through the analysis. All co-authors involved in this study had previous experiences of working with qualitative or/content analysis, which increased the study's dependability. One person, JE had the main responsibility for the analysis and the rest of the research group confirmed by checking for representativeness in the transcribed data and thereby strengthened the credibility (Elo 2014).

Finally, the results of this thesis, must be interpreted with some caution in order to be generalized or transferred to the group of community-dwelling people, with COPD or multimorbidity. First, the sample in paper I was small, and all its members were recruited from pulmonary departments in two hospitals. The participants were in a stable state, with no ongoing or recent exacerbation. People with other severe diagnoses were excluded to achieve a group predominantly with COPD according to the criteria. Therefore, this sample of participants was not necessarily a representative sample of all people diagnosed with COPD and with mild or very severe airflow limitations. However, in the AGe-FIT study we included a more representative sample and had only one exclusion criterion namely people that already had assisted living arrangements. Nevertheless, this group of participants consisted of a selected group with many diseases recruited from only one city, and with a higher percentage of men than in the general population (SCB 2015). 
Furthermore, the AGE-FIT study might have failed to include some of the most severely ill with a potentially high symptom burden. They might have declined participation due to lack of energy or bad health either from the start or during the follow-up assessments. Apart from this, the results are generalizable to a similar group of elderly community dwelling people with multimorbidity. The group of older people interviewed for the qualitative study were all selected with purposive sampling and had a high symptom burden. These result can be expected to be transferable to a similar group living in a similar context (Polit 2013).

\section{Clinical implications}

The findings from this thesis show the importance of early assessment and management of symptoms in people with COPD, and might expose an unmet need for symptom management. To reduce the total symptom burden and improve care, health care providers in clinical practice need to recognize the impact of concurrent symptoms in people with chronic disease. To recognize symptoms and symptom burden a systematic assessment and open communication about symptoms with focus on the total symptom burden is needed, taking both barriers as well as resources into consideration. A broad assessment allows health care providers to more easily compare current symptom status to the past and thereby fast capture worsening of patients' condition.

The MSAS instrument gives a good description of the multi-dimensional symptom profile and an insight of the total symptom burden in this research. However it might be a bit overwhelming to use the MSAS in day 
to day care especially in a group of older people with multimorbidity. In clinical practice health care providers are challenged to choose an instrument that on one hand includes all the relevant symptoms but at the same time still is brief enough to avoid a high response burden. A multidimensional symptom instrument that includes more than 30 items provides a detailed description of the symptom profile but may be overwhelming to a seriously ill older person. But at the same time, there is a danger to use an instrument that is too limited. It has been suggested that an instrument with 10 symptom or less are likely to exclude symptoms that burden seriously ill older people (Walke et al. 2006). Symptoms in older people need a broad assessment and each symptom needs to be communicated. Otherwise there is a risk that symptoms may be underreported or mistaken as signs of old age rather than caused by a disease.

\section{Future research}

During the work of this thesis thoughts and needs of further studies have developed.

Future studies should address:

- The use of a validated symptom instrument in day to day care to assess, manage and evaluate symptoms in older people with multimorbidity.

- Symptom maintenance and symptom self-management among older people with multimorbidity, and if possible explore differences in symptom management strategies between those with a high or low symptom burden. 
- The multidimensional symptom profile in people of all grades of COPD (mild- very severe airflow limitation), preferably with participants included from primary health care. 


\section{CONCLUSION}

The overall aim of the thesis was to describe different aspects of symptom experience from the perspective of community-dwelling people with chronic diseases. The results show that people with chronic disease experience a high symptom burden from several concurrent symptoms. There is a need for optimized care and treatment focusing on the assessment and management of the total symptom burden. The results showed that a high symptom burden was not experienced only by people with the most advanced stage of a disease and this implies the need for early symptom identification. A large proportion of older people with multimorbidity suffer a high and persistent symptom burden, and the prevalence and trajectory of pain are remarkably high. A broad symptom assessment might be beneficial to improve treatment. Older people sometimes think their high age is the reason they feel ill and experience a diversity of symptoms, and they do not always communicate these to their health-care provider. Health care providers must challenge this ageist belief that old age causes illness, and symptoms should be communicated taking both barriers as well as re-sources into consideration. 


\section{DEFINITIONS}

Table 11 Definitions of concepts used in this thesis

\begin{tabular}{ll}
\hline Concept: & Defined or described as: \\
\hline Symptoms & $\begin{array}{l}\text { A symptom can be defined as a "subjective } \\
\text { experience reflecting the bio-psycho-social } \\
\text { functioning, sensations or cognition of an individual } \\
\text { (Dodd et al 2001 p69) }\end{array}$ \\
a sign is defined as any abnormality indicative of \\
disease that is detectable by the individual or by \\
others(Dodd et al 2001 p669)
\end{tabular}




\section{SVENSK SAMMANFATTNING}

Kroniska sjukdomar tenderar att öka vid stigande ålder och äldre personer med kroniska sjukdomar erfar ofta många besvärade symptom. Att leva med många samtidigt förekommande symptom har i tidigare studier visat sig leda till en betydande försämring av den hälsorelaterade livskvalitén. Människor som lever med en hög symptombörda har ett högre vårdutnyttjande än andra personer, de tvingas oftare besöka akutmottagningen, de vårdas oftare på sjukhus och måste oftare än andra flytta till särskilt boende då de inte längre klarar av att bo kvar hemma. Sverige har en befolkningsstruktur som består av en stor andel personer över 65 år, och med en av de största andelarna av personer över 80 år i världen. Att på ett bra sätt organisera och hantera vård- och omsorg för våra äldre, förutspås enligt WHO bli ett detta århundrades största utmaningar. Det saknas dock fortfarande kunskap som rör symptomerfarenhet och symptombörda hos äldre personer med flera samtidigt förekommande sjukdomar, samt hur dessa symtom förändras över tid.

Det övergripande syftet med denna avhandling är att beskriva olika aspekter av symptombörda hos personer med kronisk sjukdom.

Avhandlingen är baserad på fyra delarbeten med både kvantitativ och kvalitativ data. Flera aspekter av fenomenet symptomerfarenhet har undersökts. Artikel (I) undersöker hur symptom erfars hos personer 
diagnostiserade med kronisk obstruktiv lungsjukdom (KOL), och om denna erfarenhet skiljer sig mellan personer diagnostiserade med moderat eller svår luftflödesbegränsning. Artikel (II och IV) baseras på sekundärdata från den randomiserade kontrollerade studien, "Dirigenter finns" - en försöksverksamhet med ett mobilt geriatrisk team. Denna studie inkluderade 382 multisjuka äldre personer. Artikel (II) är en tvärsnittsstudie och beskriver hur dessa personer erfar symptom samt vilka faktorer en hög symptombörda är relaterade till. Artikel (IV) rapporterar hur symptomerfarenhet och symptombörda förändras över tid hos gruppen multisjuka äldre, samt skillnader i symtom mellan den grupp som vård på äldre mottagningen och den grupp som haft sedvanlig vård. Artikel (III) är en kvalitativ studie baserad på intervjuer med 20 äldre multisjuka personer. Studien beskriver fenomenet "att leva med en hög symptom börda".

Personer diagnostiserade med KOL rapporterade att andnöd, muntorrhet, hosta, sömnproblem och brist på energi/trötthet var de symptom som gav den största symptombördan. Bördan av andnöd var högre hos personer med svår luftflödesbegränsning än hos dom med moderat, även symptomet brist på energi/trötthet rapporterades vara svårare och ge mer besvär av personer med svår luftflödesbegränsning. Det genomsnittliga antalet symtom per person skiljde sig inte åt statistiskt mellan deltagarna i de båda grupperna.

Artikel (II) visade att smärta var det symptom som förekom oftast, upplevdes svårast och gav mest besvär hos gruppen multisjuka äldre. Symtom som förekom i hög grad ( $(250 \%)$ hos denna grupp var brist på 
energi/trötthet och muntorrhet. Faktorer som, dålig syn, hög sannolikhet för depression, och diagnoser i matsmältningssystemet visade sig vara relaterade till en hög symptombörda hos denna grupp. Artikel IV visade att de multisjuka äldre led av en hög och ihållande symptombörda. Smärta var det symptom som förekom oftast, upplevades som svårast och gav mest besvär. Symptombördan låg på samma höga nivå i början som i slutet av den två år långa studien. Att leva med en hög symptombörda beskrevs av de multisjuka äldre som en oändlig kamp där de tvingades att antingen anpassa sig till, eller uthärda den situation de befann sig i. "Att anpassa och uthärda" tolkades som det övergripande temat i artikel III. Att leva med en hög symptombörda fick konsekvenser för det dagliga livet. Det skapade en känslomässig skörhet, kroppen svek och det liv de en gång haft var borta för alltid. Deltagarna i studien hänvisade ofta till deras höga ålder som orsak till symptombördan

Resultatet av denna avhandling visar att personer med kronisk sjukdom, erfar många samtidigt förekommande symptom. Symptombördan hos de multisjuka äldre var hög och ihållande över tid. För att om möjligt kunna minska på symtomförekomst och symptombördan, bör vårdpersonal använda skattningsskalor för att uppmärksamma, mäta, utvärdera och kommunicera symptom med personer med kronisk sjukdom. En hög symptombörda skall inte enbart förknippas med ett avancerat stadium av kronisk sjukdom, här finns utrymme att tidigt identifiera och behandla symptom. 



\section{ACKNOWLEDGEMENTS}

I would like to express my sincere gratitude to all who have supported me in different ways during the work on this thesis. Special thanks goes out to:

All participants in the studies for giving me your time, and for welcoming me in to your home during the data assessment and interviews for the AGe-FIT study.

To my main supervisor, Tiny Jaarsma thank you for your excellent scientific guidance, your patience and support. Thank you Tiny for taking me on as your doctoral student I have learned a lot from you.

Ingrid Hellström, my co-supervisor, for always listening and giving support, no matter what. Thank you for sharing your knowledge in qualitative methods and for always believing in me.

Kersti Theander, my co-supervisor. Thank you for support over these years and for generously sharing your knowledge and enthusiasm for symptom research with me.

Anne Ekdahl, co-author and project leader for the AGe-FIT, thank you for inviting me to participate in this great project and for all your good advice and support over the years.

I would like to thank Mitra Unosson Professor Emerita (my first main supervisor) for inviting me to join the COPD project. 
The research groups of both studies - the COPD study with Kristina Tödt, RPt., Magnus Kentsson, MD., Per Jakobsson, PhD MD., Mitra Unosson, RN PhD Professor emeritus., Elisabeth Skargren, PhD RPt Associate Professor and Kersti Theander, RN PhD Associate Professor.

Also, the AGe-FIT study with Anne Ekdahl, MD PhD., Amelie Lindh Mazya MD, PhD student., Ingrid Hellström RN, PhD, Associate Professor., Mitra Unosson, RN PhD , Ann-Britt Wirehn PhD, Anna Milberg MD PhD Associate Professor, Barbor Krevers OcT PhD and Tiny Jaarsma RN PhD.

To Ann Westöö, co-project leader, and Betty Brandtberg, research assistant of the Age-FIT project, thank you for always being positive, nice, and enthusiastic. It has been a joy working with you.

Elisabet Wilhelm, Department of Medical and Health Sciences, Division of Community Medicine, and Peter Garvin, Local Health Care Research and Development Unit, County Council in Östergötland for excellent statistical advice.

All doctoral students, colleagues and friends at the Department of Socialand Welfare Studies, and Division of Nursing Science, Department of Medical and Health Science at Linkoping University for your support, and friendship.

To Åsa Johansson Stark my co-worker and fellow PhD student, for endless support and friendship.

To Leonie Klompstra my fellow PhD student, for SPSS support and for being a good friend. I am so happy that you came to Sweden for your PhD studies. 
To Lisa Ring Jacobsson and Ghassan Mourad, co-workers and fellow PhD students for support during the final stage of this thesis.

To Helene Eriksson my co-worker and fellow PhD student, thank you for looking out for me when I worked too much and for being my friend. Thank you for reminding me that it is important to do something fun every now and then.

To my dear friend Susanne Vadström, thank you for endless discussions (about everything and nothing) and for keeping me company on my evening walks around Vilbergen.

To my dear mother, thank you for caring about me and my family and helping out with practical issues at home, and my Brother Jan and his family for being so understanding when I just didn't have time for our yearly family gatherings (and we had to celebrate everyone's birthday, Easter and Christmas at the same time).

And last but not at least, I thank my beloved family Bo, Rebecca \& Patrik, Robin \& Eva I am so grateful and proud to have all of you in my life. A special thank you to Robin for helping out with the transcription of the interviews, and for language editing, and to Eva for the lovely cover picture of this thesis. Most of all a very special thank you to my beloved husband Bo, for your endless support and never-ending patience. Now, finally we can set sail and leave together for new adventures.

Thank You All // Jeanette 
For providing financial support for this thesis I would like to thank: the Faculty of Medicine and Health Sciences, Linkoping University; the Department of Social and Welfare Studies, Division of Health, Activity and Care., the County Council of Östergotland., the Signe and Olof Wallenius trust fund., the Solstickan trust fund; the Swedish Association of Geriatric Medicine with support from Mundipharma., the Swedish Dementia Association, and the Lions trust fund. 


\section{REFERENCES}

Abdulla, A., Adams, N., Bone, M., Elliott, A.M., Gaffin, J., Jones, D., Knaggs, R., Martin, D., Sampson, L., Schofield, P. \& British Geriatric, S. (2013)

Guidance on the management of pain in older people. Age Ageing, 42 Suppl 1, i1-57.

Aldred, H., Gott, M. \& Gariballa, S. (2005) Advanced heart failure: impact on older patients and informal carers. Journal of Advanced Nursing, 49(2), 116124.

Antunes, B., Harding, R. \& Higginson, I.J. (2014) Implementing patient-reported outcome measures in palliative care clinical practice: A systematic review of facilitators and barriers. Palliative Medicine, 28(2), 158-175.

Bausewein, C., Booth, S., Gysels, M., Kuhnbach, R., Haberland, B. \& Higginson, I.J. (2010) Understanding breathlessness: cross-sectional comparison of symptom burden and palliative care needs in chronic obstructive pulmonary disease and cancer. Journal of Palliative Medicine, 13(9), 110918.

Beauchet, O., Launay, C.P., Merjagnan, C., Kabeshova, A. \& Annweiler, C. (2014) Quantified Self and Comprehensive Geriatric Assessment: Older Adults Are Able to Evaluate Their Own Health and Functional Status. PLOS ONE, 9(6), 1-5.

Bentsen, S.B., Gundersen, D., Assmus, J., Bringsvor, H. \& Berland, A. (2013) Multiple symptoms in patients with chronic obstructive pulmonary disease in Norway. Nursing $\mathcal{E}$ health sciences, 15(3), 292-9.

Bergman, H., Beland, F., Lebel, P., Contandriopoulos, A.P., Tousignant, P., Brunelle, Y., Kaufman, T., Leibovich, E., Rodriguez, R. \& Clarfield, M. (1997) Care for Canada's frail elderly population: fragmentation or integration? Canadian Medical Association journal, 157(8), 1116-21.

Black, H.K., Santanello, H.R. \& Caruso, C.J. (2013) Managing threats against control in old age: a narrative inquiry. Nursing research, 62(6), 430-7.

Blinderman, C.D., Homel, P., Billings, J.A., Portenoy, R.K. \& Tennstedt, S.L. (2008) Symptom distress and quality of life in patients with advanced congestive heart failure. Journal of Pain E Symptom Management, 35(6), 594-603.

Blinderman, C.D., Homel, P., Billings, J.A., Tennstedt, S. \& Portenoy, R.K. (2009) Symptom distress and quality of life in patients with advanced chronic obstructive pulmonary disease. Journal of Pain $\mathcal{E}$ Symptom Management, 38(1), 115-123. 
Boeckxstaens, P. \& De Graaf, P. (2011) Primary care and care for older persons: Position Paper of the European Forum for Primary Care. Quality in Primary Care, 19(6), 369-389.

Browall, M., Kenne Sarenmalm, E., Nasic, S., Wengström, Y. \& GastonJohansson, F. (2013) Validity and Reliability of the Swedish Version of the Memorial Symptom Assessment Scale (MSAS): An Instrument for the Evaluation of Symptom Prevalence, Characteristics, and Distress. Journal of Pain E Symptom Management, 46(1), 131-141.

Brusasco, V., Crapo, R. \& Viegi, G. (2005) Coming together: the ATS/ERS consensus on clinical pulmonary function testing. European Respiratory Journal, 26(1), 1-2.

Burgel, P.R., Escamilla, R., Perez, T., Carre, P., Caillaud, D., Chanez, P., Pinet, C., Jebrak, G., Brinchault, G., Court-Fortune, I., Paillasseur, J.L., Roche, N. \& Committee, I.B.S. (2013) Impact of comorbidities on COPD-specific health-related quality of life. Respiratory medicine 107(2), 233-41.

Cameron, J., Worrall-Carter, L., Page, K. \& Stewart, S. (2010) Self-care behaviours and heart failure: Does experience with symptoms really make a difference? European Journal of Cardiovascular Nursing, 9(2), 92100 .

Chaudhry, S.I., Murphy, T.E., Gahbauer, E., Sussman, L.S., Allore, H.G. \& Gill, T.M. (2013) Restricting symptoms in the last year of life: a prospective cohort study. JAMA Internal Medicine, 173(16), 1534-1540 7p.

Chochinov, H.M., Hack, T., Hassard, T., Kristjanson, L.J., McClement, S. \& Harlos, M. (2005) Understanding the will to live in patients nearing death. Psychosomatics, 46(1), 7-10.

Christensen, K., Doblhammer, G., Rau, R. \& Vaupel, J.W. (2009) Ageing populations: the challenges ahead. The Lancet, 374(9696), 1196-1208.

Cleeland, C.S. (2007) Symptom burden: multiple symptoms and their impact as patient-reported outcomes. National Cancer Institute monograph, (37), 16-21.

Combs, S., Kluger, B.M. \& Kutner, J.S. (2013) Research priorities in geriatric palliative care: nonpain symptoms. Journal of Palliative Medicine, 16(9), 1001-7.

Condelius, A., Edberg, A.-K., Jakobsson, U. \& Hallberg, I.R. (2007) Hospital admissions among people 65+ related to multimorbidity, municipal and outpatient care. Archives of Gerontology and Geriatrics, 46(1), 41-55.

Conradsson, M., Rosendahl, E., Littbrand, H., Gustafson, Y., Olofsson, B. \& Lövheim, H. (2013) Usefulness of the Geriatric Depression Scale 15-item version among very old people with and without cognitive impairment. Aging \& Mental Health, 17(5), 638. 
de Waal, M.W., van der Weele, G.M., van der Mast, R.C., Assendelft, W.J. \& Gussekloo, J. (2012) The influence of the administration method on scores of the 15-item Geriatric Depression Scale in old age. Psychiatry Research 197(3), 280-4.

Decramer, M., Janssens, W. \& Miravitlles, M. Chronic obstructive pulmonary disease. The Lancet, 379, 1341-1351.

Dodd, M.J., S. Facione, N. Faucett, J. Froelicher, E. S. Humphreys, J. Lee, K. Miaskowski, C. Puntillo, K. Rankin, S. Taylor, D. (2001) Advancing the science of symptom management. Journal of Advanced Nursing, 33(5), 668676.

Dziechciaż, M. \& Filip, R. (2014) Biological psychological and social determinants of old age: Bio-psycho-social aspects of human aging. Annals of Agricultural and Environmental Medicine, 21(4), 835-838.

Ebrahimi, Z., Wilhelmson, K., Eklund, K., Moore, C.D. \& Jakobsson, A. (2013) Health despite frailty: exploring influences on frail older adults' experiences of health. Geriatric Nursing, 34(4), 289-94.

Ekdahl, A.W., Wirehn, A.B., Alwin, J., Jaarsma, T., Unosson, M., Husberg, M., Eckerblad, J., Milberg, A., Krevers, B. \& Carlsson, P. (2015) Costs and Effects of an Ambulatory Geriatric Unit (the AGe-FIT Study): A Randomized Controlled Trial. Journal of the American Medical Directors Association, 16(6), 497-503.

Elias, T. \& Lowton, K. (2014) Do those over 80 years of age seek more or less medical help? A qualitative study of health and illness beliefs and behaviour of the oldest old. Sociology of health $\mathcal{E}$ illness, 36(7), 970-85.

Eller, L.S., Corless, I., Bunch, E.H., Kemppainen, J., Holzemer, W., Nokes, K., Portillo, C. \& Nicholas, P. (2005) Self-care strategies for depressive symptoms in people with HIV disease. Journal of Advanced Nursing, 51(2), 119-130.

Ellis, G., Whitehead, M.A., Robinson, D., O'Neill, D. \& Langhorne, P. (2011)

Comprehensive geriatric assessment for older adults admitted to hospital: meta-analysis of randomised controlled trials. British Medical Journal, 343 p. 1-10.

Elo S, K.M., Kanste O, Pölkki T, Kati Utriainen, Kyngäs H. (2014) Qualitative Content Analysis: A Focus on Trustworthiness. SAGE Open, JanuaryMarch 1-10.

Estabrooks, C.A., Hoben, M., Poss, J.W., Chamberlain, S.A., Thompson, G.N., Silvius, J.L. \& Norton, P.G. (2015) Dying in a nursing home: treatable symptom burden and its link to modifiable features of work context Journal of the American Medical Directors Association 16(6), 515-20.

EU (2015)European Commission Public health Major and chronic diseases Policy Accecced October 9 2015.at

http://ec.europa.eu/health/major_chronic_diseases/policy/index_en.htm 
EU (2014) Population structure and ageing by major age groups, EU-28, 2014-50 http://ec.europa.eu/eurostat/statisticsexplained/index.php/Population_structure_and_ageing\#Further_Eurosta t_information Accessed 2015 Sept 18.

http://ec.europa.eu/eurostat/statisticsexplained/index.php/Population_structure_and_ageing\#Further_Eurosta t_information.

Field, A. (2009) Discovering statistics using SPSS : (and sex and drugs and rock ' $n$ ' roll), Los Angeles ; London : SAGE, cop. 2009 3. ed.

Fierro-Carrion, G., Mahler, D.A., Ward, J. \& Baird, J.C. (2004) Comparison of continuous and discrete measurements of dyspnea during exercise in patients with COPD and normal subjects. CHEST, 125(1), 77-84.

Fletcher, M.J. \& Dahl, B.H. (2013) Expanding nursing practice in COPD: key to providing high-quality, effective, and safe patient care? Primary care respiratory journal: journal of the General Practice Airways Group, 22(2), 230

Folstein, M.F., Folstein, S.E. \& McHugh, P.R. (1975) Mini-mental state: A practical method for grading the cognitive state of patients for the clinician. Journal of Psychiatric Research, 12(3), 189-198.

Frank, L., Kleinman, L., Rentz, A., Ciesla, G., Kim, J.J. \& Zacker, C. (2002) Health-related quality of life associated with irritable bowel syndrome: comparison with other chronic diseases. Clinical Therapeutics 24(4), 67589;

Fratiglioni L, M.A., Meinow B, Karp A (2010) Multipla hälsoproblem bland personer över 60 år -En systematisk litteraturöversikt om förekomst, konsekvenser och vård, En rapport från Sociala rådet, SOU 2010:48 Stockholm. pp. 1-96.

Gagnon, M., Jacob, J.D. \& McCabe, J. (2015) Locating the qualitative interview: Reflecting on space and place in nursing research. Journal of Research in Nursing, 20(3), 203-215.

Gapstur, R.L. (2007) Symptom burden: a concept analysis and implications for oncology nurses. Oncology nursing forum, 34(3), 673-80.

Gilleard, C. \& Higgs, P. (2013) The fourth age and the concept of a 'social imaginary': A theoretical excursus. Journal of Aging Studies, 27, 368-376.

Goldberg, R.J., Spencer, F.A., Szklo-Coxe, M., Tisminetzky, M., Yarzebski, J., Lessard, D., Gore, J.M. \& Gaasch, W. (2010) Symptom presentation in patients hospitalized with acute heart failure. Clinical cardiology, 33(6), E73-80.

Graneheim, U.H. \& Lundman, B. (2004) Qualitative content analysis in nursing research: concepts, procedures and measures to achieve trustworthiness. Nurse education today, 24(2), 105-12. 
Gurner, U. \& Thorslund, M. (2001) Serie: Den aldre patienten Helhetssyn behovs i varden av multisviktande aldre Forslag till forandring av vardoch omsorgsstrukturen i Stockholms lan. LAKARTIDNINGEN, 25962603.

HajGhanbari, B., Holsti, L., Road, J.D. \& Darlene Reid, W. (2012) Pain in people with chronic obstructive pulmonary disease (COPD). Respiratory Medicine, 106, 998-1005.

Hedenstrom, H., Malmberg, P. \& Agarwal, K. (1985) Reference values for lung function tests in females. Regression equations with smoking variables. Bulletin européen de physiopathologie respiratoire, 21(6), 551-7.

Hedenstrom, H., Malmberg, P. \& Fridriksson, H.V. (1986) Reference values for lung function tests in men: regression equations with smoking variables. Upsala journal of medical sciences / published by the Upsala Medical Society, 91(3), 299-310.

Hofsø, K., Rustøen, T., Cooper, B.A., Bjordal, K. \& Miaskowski, C. (2013) Original Article: Changes Over Time in Occurrence, Severity, and Distress of Common Symptoms During and After Radiation Therapy for Breast Cancer. Journal of Pain and Symptom Management, 45, 980-1006.

Huang, C.Q., Dong, B.R., Lu, Z.C., Yue, J.R. \& Liu, Q.X. (2010) Chronic diseases and risk for depression in old age: a meta-analysis of published literature. Ageing Research Reviews, 9(2), 131-41.

ICN International Council of Nurses, 2012 The Code of ethics for nurses, Geneva, Switzerland Accecced at http://www.icn.ch/who-we-are/codeof-ethics-for-nurses/ November 12015

Jablonski, A., Gift, A. \& Cook, K.E. (2007) Symptom assessment of patients with chronic obstructive pulmonary disease. Western Journal of Nursing Research, 29(7), 845-863.

Kane, R.L.O., Joseph G. Abrass, Itamar B. Resnick, Barbara (2013) Essentials of clinical geriatrics. In McGraw-Hill's AccessMedicineNew York, N.Y: McGraw Hill Medical, c2013, 7th ed.

Kaye, A.D., Baluch, A. \& Scott, J.T. (2010) Pain management in the elderly population: a review. The Ochsner Journal, 10(3), 179-187.

Kaye, A.D., Baluch, A.R., Kaye, R.J., Niaz, R.S., Kaye, A.J., Liu, H. \& Fox, C.J. (2014) Geriatric pain management, pharmacological and nonpharmacological considerations. Psychology \& Neuroscience, 7(1), 15-26.

Knapp, K., Cooper, B., Koetters, T., Cataldo, J., Dhruva, A., Paul, S.M., West, C., Aouizerat, B.E. \& Miaskowski, C. (2012) Original Article: Trajectories and Predictors of Symptom Occurrence, Severity, and Distress in Prostate Cancer Patients Undergoing Radiation Therapy. Journal of Pain and Symptom Management, 44, 486-507. 
Kuzuya, M., Enoki, H., Hasegawa, J., Izawa, S., Hirakawa, Y., Shimokata, H. \& Akihisa, I. (2011) Regular Research Article: Impact of Caregiver Burden on Adverse Health Outcomes in Community-Dwelling Dependent Older Care Recipients. The American Journal of Geriatric Psychiatry, 19, 382-391.

Landi, F., Onder, G., Cesari, M., Gambassi, G., Steel, K., Russo, A., Lattanzio, F. \& Bernabei, R. (2001) Pain management in frail, community-living elderly patients. Archives of Internal Medicine, 161(22), 2721-4.

Landi, F., Onder, G., Cesari, M., Russo, A., Barillaro, C. \& Bernabei, R. (2005) Pain and its relation to depressive symptoms in frail older people living in the community: an observational study. Journal of Pain $\mathcal{E}$ Symptom Management, 29(3), 255-262.

Larsson, K. \& Thorslund, M. (2006) Chapter 8: Old people's health. Scandinavian Journal of Public Health, 34(3), 185-198.

Lenz, E.R., Pugh, L.C., Milligan, R.A., Gift, A. \& Suppe, F. (1997) The middlerange theory of unpleasant symptoms: an update. Advances in Nursing Science, 19(3), 14-27.

Lindberg, A., Bjerg, A., Ronmark, E., Larsson, L.G. \& Lundback, B. (2006) Prevalence and underdiagnosis of COPD by disease severity and the attributable fraction of smoking Report from the Obstructive Lung Disease in Northern Sweden Studies. Respiratory medicine, 100(2), 264-72.

Marc, L.G., Raue, P.J. \& Bruce, M.L. (2008) Screening performance of the 15-item geriatric depression scale in a diverse elderly home care population. The American journal of geriatric psychiatry, 16(11), 914-21.

Marengoni, A., Angleman, S., Melis, R., Mangialasche, F., Karp, A., Garmen, A., Meinow, B. \& Fratiglioni, L. (2011) Review: Aging with multimorbidity: A systematic review of the literature. Ageing Research Reviews, $10,430-439$.

McEvoy, L. \& Duffy, A. (2008) Holistic practice - a concept analysis. Nurse Education in Practice, 8(6), 412-419.

McMurray, J.J.V., Adamopoulos, S., Anker, S.D., Auricchio, A., Böhm, M., Dickstein, K., Falk, V., Filippatos, G., Fonseca, C., Gomez-Sanchez, M.A., Jaarsma, T., Køber, L., Lip, G.Y.H., Maggioni, A.P., Parkhomenko, A., Pieske, B.M., Popescu, B.A., Rønnevik, P.K., Rutten, F.H. \& Schwitter, J. (2012) ESC Guidelines for the diagnosis and treatment of acute and chronic heart failure 2012. European Journal of Heart Failure, 14(8), 803.

Mitchell, A.J. (2009) A meta-analysis of the accuracy of the mini-mental state examination in the detection of dementia and mild cognitive impairment. Journal of Psychiatric Research, 43, 411-431.

Mitchell, A.J., Bird, V., Rizzo, M. \& Meader, N. (2010) Review: Diagnostic validity and added value of the geriatric depression scale for depression in primary care: A meta-analysis of GDS30 and GDS15. Journal of Affective Disorders, 125, 10-17. 
Mitchell, G. (2015) Use of interviews in nursing research. Nursing Standard, 29(43), 44-48.

Molton, I.R. \& Terrill, A.L. (2014) Overview of persistent pain in older adults. American Psychologist, 69(2), 197-207.

Morse, J.M. (2008) Confusing categories and themes. Qualitative Health Research, 18(6), 727-728.

Negewo, N.A., McDonald, V.M. \& Gibson, P.G. (2015) Comorbidity in chronic obstructive pulmonary disease. Respiratory Investigation, 53(6), 249-258.

Newcomb, P. (2010) Using Symptom Management Theory to Explain how Nurse Practitioners Care for Children with Asthma. Journal of Theory Construction $\mathcal{E}$ Testing, 14(2), 40-44.

Ornstein, K., Wajnberg, A., Kaye-Kauderer, H., Winkel, G., DeCherrie, L., Zhang, M. \& Soriano, T. (2013) Reduction in symptoms for homebound patients receiving home-based primary and palliative care. Journal of Palliative Medicine, 16(9), 1048-54.

Paepe, P.D., Petrovic, M., Outtier, L., G, G.V.M. \& Buylaert, W. (2013) Drug interactions and adverse drug reactions in the older patients admitted to the emergency department. Acta Clinica Belgica., 68(1), 15-21.

Pettersson, G., Berterö, C., Unosson, M. \& Börjeson, S. (2014) Symptom prevalence, frequency, severity, and distress during chemotherapy for patients with colorectal cancer. Supportive Care In Cancer 22(5), 1171-1179.

Polit, D.F.B., Cheryl Tatano (2013) Essentials of nursing research : appraising evidence for nursing practice, Philadelphia : Wolters Kluwer Health/Lippincott Williams \& Wilkins, cop. 2014 8. ed.

Portenoy, R.K., Thaler, H.T., Kornblith, A.B., Lepore, J.M., Friedlander-Klar, H., Kiyasu, E., Sobel, K., Coyle, N., Kemeny, N., Norton, L. \& et al. (1994) The Memorial Symptom Assessment Scale: an instrument for the evaluation of symptom prevalence, characteristics and distress. European Journal of Cancer, 30A(9), 1326-36.

Rabe, K.F., Hurd, S., Anzueto, A., Barnes, P.J., Buist, S.A., Calverley, P., Fukuchi, Y., Jenkins, C., Rodriguez-Roisin, R., van Weel, C. \& Zielinski, J. (2007) Global strategy for the diagnosis, management, and prevention of chronic obstructive pulmonary disease: GOLD executive summary. . American journal of respiratory and critical care medicine, 176(6), 532-55.

Rastogi, R. \& Meek, B.D. (2013) Management of chronic pain in elderly, frail patients: finding a suitable, personalized method of control. Clinical Interventions in Aging, 8, 37-46.

Riegel, B., Dickson, V.V., Cameron, J., Johnson, J.C., Bunker, S., Page, K. \& Worrall-Carter, L. (2010) Symptom recognition in elders with heart failure. Journal of nursing scholarship, 42(1), 92-100. 
Ritchie, C., Dunn, L.B., Paul, S.M., Cooper, B.A., Skerman, H., Merriman, J.D., Aouizerat, B., Alexander, K., Yates, P., Cataldo, J. \& Miaskowski, C. (2014) Differences in the Symptom Experience of Older Oncology Outpatients. Journal of Pain and Symptom Management, 47(4), 697-709.

Rockwood, K., Song, X., MacKnight, C., Bergman, H., Hogan, D.B., McDowell, I. \& Mitnitski, A. (2005) A global clinical measure of fitness and frailty in elderly people. Canadian Medical Association journal 173(5), 489-95.

Rosen, H.I., Bergh, I.H., Schwartz-Barcott, D. \& Martensson, L.B. (2014) The Recovery Process After Day Surgery Within the Symptom Management Theory. Nursing Forum. 49(2), 100-109

Royall, D.R., Schillerstrom, J.E., Piper, P.K. \& Chiodo, L.K. (2007) Depression and mortality in elders referred for geriatric psychiatry consultation. Journal of the American Medical Directors Associatio, 8(5), 318-21.

Rubenstein, L.Z., Stuck, A.E., Siu, A.L. \& Wieland, D. (1991) Impacts of geriatric evaluation and management programs on defined outcomes: overview of the evidence. Journal Of The American Geriatrics Society, 39(9 Pt 2), 8S.

Salanitro, A.H., Hovater, M., Hearld, K.R., Roth, D.L., Sawyer, P., Locher, J.L., Bodner, E., Brown, C.J., Allman, R.M. \& Ritchie, C.S. (2012) Symptom burden predicts hospitalization independent of comorbidity in community-dwelling older adults. Journal of The American Geriatrics Society, 60(9), 1632-7.

Santos-Eggimann, B., Cuénoud, P., Spagnoli, J. \& Junod, J. (2009) Prevalence of Frailty in Middle-Aged and Older Community-Dwelling Europeans Living in 10 Countries. The Journals of Gerontology Series A: Biological Sciences and Medical Sciences, 64(6), 675-681.

SCB Statistics in Sweden, Population projections 2014 http://www.scb.se/en_/Finding-statistics/Statistics-by-subjectarea/Population/Population-projections/Population-projections/AktuellPong/14505/Current-forecast/The-future-population-of-Sweden20152060/273436/ Accessed 2015 Sept 19

Schäfer, I., Hansen, H., Schön, G., Höfels, S., Altiner, A., Dahlhaus, A., Gensichen, J., Riedel-Heller, S., Weyerer, S., Blank, W.A., König, H.-H., von dem Knesebeck, O., Wegscheider, K., Scherer, M., van den Bussche, H. \& Wiese, B. (2012) The influence of age, gender and socio-economic status on multimorbidity patterns in primary care. First results from the multicare cohort study. BMC Health Services Research, 12, 89-89.

SFS Svensk författningssamling / Körkortslag (1998:488)

https://www.riksdagen.se/sv/DokumentLagar/Lagar/Svenskforfattningssamling/Korkortslag-1998488_sfs-1998488/ Accessed 2015 Sept 18. 
SFS Svensk författningssamling / Socialförsäkringsbalk (2010:110) http://www.riksdagen.se/sv/DokumentLagar/Lagar/Svenskforfattningssamling/Socialforsakringsbalk201011_sfs-2010-110/?bet=2010:110 Accessed 2015 Sept 18

SFS Svensk författningssamling / Vallag (1997:157) https:/www.riksdagen.se/sv/DokumentLagar/Lagar/Svenskforfattningssamling/Vallag-1997157_sfs-1997-157/ Accessed 2015 Sept 18.

Sheik, J. \& Yesavage, J. (1986) Geriatric Depression Scale (GDS): recent evidence and development of a shorter version. Clinical Gerontologist, 5(165-172).

Sheppard, K.D., Brown, C.J., Hearld, K.R., Roth, D.L., Sawyer, P., Locher, J.L., Allman, R.M. \& Ritchie, C.S. (2013) Symptom burden predicts nursing home admissions among older adults. Journal of Pain $\mathcal{E}$ Symptom Management, 46(4), 591-7.

Simren, M., Svedlund, J., Posserud, I., Bjornsson, E.S. \& Abrahamsson, H. (2006) Health-related quality of life in patients attending a gastroenterology outpatient clinic: functional disorders versus organic diseases. Clinical Gastroenterology And Hepatology: 4(2), 187-95.

Singer, S.J., Burgers, J., Friedberg, M., Rosenthal, M.B., Leape, L. \& Schneider, E. (2011) Defining and measuring integrated patient care: promoting the next frontier in health care delivery. Medical care research and review, 68(1), 112-27.

Sletvold, O., Tilvis, R., Jonsson, A., Schroll, M., Snaedal, J., Engedal, K., SchultzLarsen, K. \& Gustafson, Y. (1996) Geriatric work-up in the Nordic countries. The Nordic approach to comprehensive geriatric assessment. Danish Medical Bulletin, 43(4), 350-9.

Smith, M.J.L., Patricia R. (2014a) Middle range theory for nursing (3rd ed.) Chapter 7 Theory of Symptom Management, Springer Publishing Co, New York, NY, US.p 141-165

Smith, M.J.L., Patricia R. (2014b) Middle range theory for nursing (3rd ed.) Chapter 8 Theory of Unpleasant Symptoms Springer Publishing Co, New York, NY, US.p 165-195.

Stewart, T.L., Chipperfield, J.G., Perry, R.P. \& Weiner, B. (2012) Attributing illness to 'old age:' consequences of a self-directed stereotype for health and mortality. Psychology $\mathcal{E}$ health 27(8), 881-97.

Theander, K., Hasselgren, M., Luhr, K., Eckerblad, J., Unosson, M. \& Karlsson, I. (2014) Symptoms and impact of symptoms on function and health in patients with chronic obstructive pulmonary disease and chronic heart failure in primary health care. International journal of chronic obstructive pulmonary disease, 9, 785-94.

Theander, K. \& Unosson, M. (2004) Fatigue in patients with chronic obstructive pulmonary disease. Journal of Advanced Nursing, 45(2), 172-177. 
Theander, K. \& Unosson, M. (2011) No gender differences in fatigue and functional limitations due to fatigue among patients with COPD. Journal of Clinical Nursing, 20(9-10), 1303-10.

Tranmer, J.E., Heyland, D., Dudgeon, D., Groll, D., Squires-Graham, M. \& Coulson, K. (2003) Measuring the symptom experience of seriously ill cancer and noncancer hospitalized patients near the end of life with the Memorial Symptom Assessment Scale. Journal of Pain E Symptom Management, 25(5), 420-429.

Tse, M., Wan, V.T. \& Wong, A.M. (2013) Pain and pain-related situations surrounding community-dwelling older persons Journal of Clinical Nursing, 22(13-14), 1870-9.

Wajnberg, A., Ornstein, K., Zhang, M., Smith, K.L. \& Soriano, T. (2013) Symptom burden in chronically ill homebound individuals. Journal of the American Geriatrics Society, 61(1), 126-31.

Walke, L.M., Byers, A.L., McCorkle, R. \& Fried, T.R. (2006) Symptom assessment in community-dwelling older adults with advanced chronic disease. Journal of Pain E Symptom Management, 31(1), 31-7.

Walke, L.M., Gallo, W.T., Tinetti, M.E. \& Fried, T.R. (2004) The burden of symptoms among community-dwelling older persons with advanced chronic disease. Archives of Internal Medicine, 164(21), 2321-4.

van Dam van Isselt, E.F., Groenewegen-Sipkema, K.H., Spruit-van Eijk, M., Chavannes, N.H., de Waal, M.W.M., Janssen, D.J.A. \& Achterberg, W.P. (2014) Pain in patients with COPD: a systematic review and metaanalysis. BMJ Open, 4(9), p 1-17.

Waterworth, S. \& Jorgensen, D. (2010) It's not just about heart failure -- voices of older people in transition to dependence and death. Health $\mathcal{E}$ Social Care in the Community, 18(2), 199-207.

Vestbo, J., Hurd, S.S., Agustí, A.G., Jones, P.W., Vogelmeier, C., Anzueto, A., Barnes, P.J., Fabbri, L.M., Martinez, F.J., Nishimura, M., Stockley, R.A., Sin, D.D. \& Rodriguez-Roisin, R. (2013) Global Strategy for the Diagnosis, Management, and Prevention of Chronic Obstructive Pulmonary Disease: GOLD Executive Summary. American Journal of Respiratory \& Critical Care Medicine, 187(4), 347-365 19p.

WHO (2003) WHO ICF Checklist. Appendix 1 Brief Health Information.

Geneva: World Health Organization Available from: http://www.who.int/classifications/icf/training/icfchecklist.pdf

WHO (2008) The World Health Report 2008. Primary Health Care-Now more than ever. The World Health Report p. 8. Available http://www.who.int/whr/2008/whr08_en.pdf, 1-148.

WHO (2014) Global status report on noncommunicable diseases 2014. Vol. 2015 http://www.who.int/nmh/publications/ncd-status-report-2014/en/. 
Wieland, D. (2003) The effectiveness and costs of comprehensive geriatric evaluation and management. Critical reviews in oncology/hematology, 48(2), 227-37.

WMA (2013) Declaration of Helsinki - Ethical Principles for Medical Research Involving Human Subjects. World Medical Journal, 59(5), 199-202.

Wolff, J.L., Starfield, B. \& Anderson, G. (2002) Prevalence, Expenditures, and Complications of Multiple Chronic Conditions in the Elderly. Archives of Internal Medicine, 162(20), 2269-2276.

Zambroski, C.H., Moser, D.K., Bhat, G. \& Ziegler, C. (2005) Impact of symptom prevalence and symptom burden on quality of life in patients with heart failure. European journal of cardiovascular nursing, 4(3), 198-206. 



\section{Papers}

The articles associated with this thesis have been removed for copyright reasons. For more details about these see:

http://urn.kb.se/resolve?urn=urn:nbn:se:liu:diva-122742 